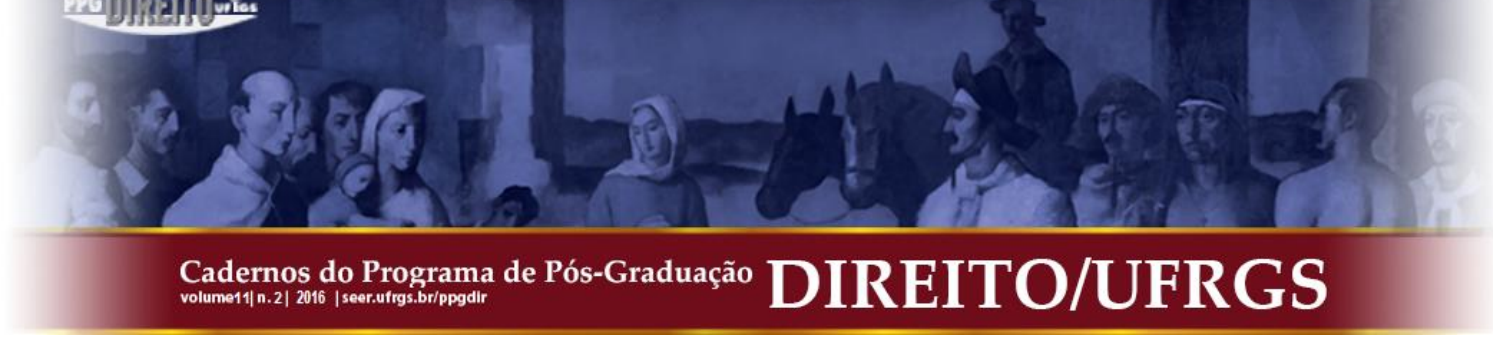

\title{
ASPECTOS DO “DIREITO PENAL DESEJADO” EM COMENTÁRIOS DE MÍDIAS SOCIAIS: UMA ANÁLISE CRÍTICA
}

\author{
ASPECTS OF THE “CRIMINAL LAW DESIRED” ON COMMENTS OF SOCIAL MEDIA:
}

\author{
A CRITICAL ANALYSIS
}

\author{
Júlio César Pompeu* \\ Marlon Amaral Hungaro **
}

\begin{abstract}
RESUMO: Analisa-se qual é o "direito penal desejado" expresso por internautas atualmente. Fontes bibliográficas e materiais jornalísticos online (mídia social) serão utilizados para dar resposta à seguinte indagação: há um "direito penal desejado", expresso por internautas, no Brasil? Havendo esse "direito", qual a influência dos veículos midiáticos para a formação desse discurso? A pesquisa científica ganha relevância por apresentar-se às vésperas da promulgação do novo Código Penal (PLS n ${ }^{\circ}$ 236/2012), notavelmente recrudescido, que dá voz à opinião pública advinda das mídias sociais. Assim, por amostragem, a análise possibilita perquirir acerca dos aspectos desse "direito penal" almejado na Internet. A delimitação da análise dá-se a um linchamento ocorrido em julho de 2015, em São Luís/MA. São analisadas todas as matérias publicadas pelo jornal online Extra (Globo) sobre o referido tema, assim como os comentários ali gerados em nove dias. Parte-se da suposição de que o "direito penal desejado" atualmente apresenta-se similar ao efetivamente exercido num passado remoto: a flagelação corporal. A Análise Crítica do Discurso propicia a imersão no problema de pesquisa. Nesse sentido, há a confirmação da hipótese: o discurso predominante nos comentários dos internautas está direcionado a um "direito penal" deveras punitivista (legitimação discursiva da prática da vingança privada e da punição corporal). Contudo, esse discurso não pode ser considerado isoladamente, pois foi possível notar que a mídia patentemente influencia na (de)formação do discurso dos internautas, quando se posiciona de um modo (matéria predominantemente informativa) ou de outro (conteúdo opinativo ou enviesado).
\end{abstract}

PAlaVRAS-CHAVE: Direito Penal Desejado. Mídia de Massa. Análise Crítica do Discurso.
ABSTRACT: This research analyzes what is called as the "criminal law desired" by internet users in contemporary social media. Bibliographical sources and online journalistic material (social media) were used to answer the following question: is there a "criminal law desired" expressed by Internet users in Brazil? If this "criminal law" exists, which is the media influence in the formation of this discourse? Scientific research is relevant to be made on the eve of the promulgation of the new Criminal Code (PLS No. 236/2012), notably austere, giving voice to public opinion arising out of social media. The study was delimited by the analysis of a lynching occurred in July 2015 in the city of São Luis, State of Maranhão. All the articles published by online newspaper Extra (Globo) were analyzed, as well as the readers' comments written during nine days - period in which all the materials and comments were published. The assumption is that the "criminal law currently desired" is the same that existed in a distant past: corporal punishment. A Critical Discourse Analysis provides immersion in the research problem. In this sense, there is the confirmation of the hypothesis: the dominant discourse in the comments of Internet users are directed to a more punitive "criminal law" (which legitimates the practice of private revenge and corporal punishment). However, this discourse cannot be considered in isolation, since it was noticeable the media influence in the formation/deformation of the discourse of internet users, which varies according the content published, if it is predominantly informative, an opinion or a biased content).

KEYWORDS: "Criminal Law Desired". Mass media. Critical Discourse Analysis.

SUMÁRIO: Introdução. 1 Perspectivas Punitivas no atual Contexto Social. 2 O Projeto de Novo Código Penal (Pls N 236/2012). 3 Procedimentos de Análise. 3.1 A Descrição do Discurso. 3.2 Os Modos de Operação da Ideologia. 4 O Caso do Linchamento no Maranhão. 4.1 Matérias e Comentários. 4.2 Panorama Geral dos Comentários. 4.3 O "Direito Penal Desejado" nos Comentários. 4.4 Relação entre Matérias e Comentários. Considerações Finais. Referências.

\footnotetext{
* Doutor em Psicologia pela Universidade Federal do Espírito Santo (UFES). Mestre em Direito pela Pontifícia Universidade Católica do Rio de Janeiro (PUC-RJ). Professor Programa de Pós-Graduação em Direito da Universidade Federal do Espírito Santo (UFES).

** Mestre em Direito pela Universidade Federal do Espírito Santo (UFES). Especialista em Direito Constitucional pela Faculdade de Direito Prof. Damásio de Jesus (FSSJ), São Paulo.
} 


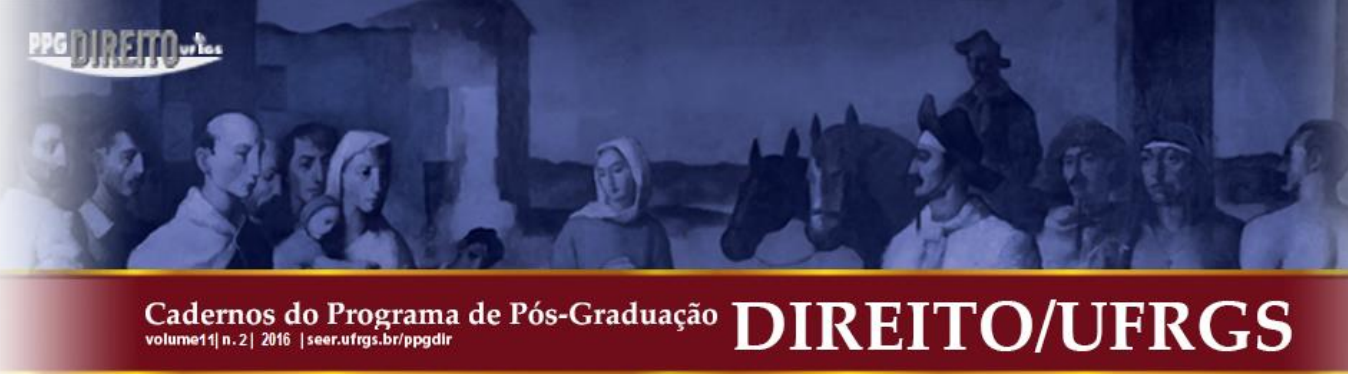

Ainda, optou-se por investigar, além dos próprios comentários, a forma que as notícias foram divulgadas no referenciado veículo midiático. Assim, nada obstante o "direito penal desejado" ser o objetivo central desta pesquisa, entende-se necessário questionar se a partir de matérias de cunho informativo ou opinativo haveria alguma tendência destas resplandecida nos comentários acostados. Assim, as fontes de pesquisa serão as midiáticas (notícias e comentários veiculados nos sítios do Extra/Globo) - portanto, também documental Gil (2012), posto que matérias jornalísticas também pertencerem à história cultural (BURKE, 2008, p. 7).

No ensejo de buscar aspectos do "direito penal desejado" por internautas, uma pesquisa de opinião (levantamento) será efetuada tendo por parâmetro a análise dos comentários publicados na Internet sobre o caso de um suposto evento criminal (roubo), que fatidicamente calhou em "justiçamento" público (linchamento) ocorrido, no dia 6 de julho de 2015, em São Luís/MA.

Pode-se asseverar, no contexto atual, que o clamor popular se faz ouvir com intensidade, justamente, pelas condições de possibilidade emanadas da Internet, sendo os computadores, enquanto sistema de comunicação, "amplificadores e extensões da mente humana", como ensina Castells (2001, p. 69).

A título de exemplificação dessa influência, destacam-se as passeatas ocorridas no Brasil, em 2013, a fim de reivindicar melhorias sociais (GARCIA, 2013), assim como os protestos promovidos contra o Governo Federal no dia 15 de março de 2015 (dois milhões de pessoas) e no dia 13 de março de 2016 (3,3 milhões de pessoas) (MENEZES, 2016), todos promovidos majoritariamente pela Internet. Devido a isso, restou evidenciado que tais movimentos sociais foram expressivos, em questão numérica, devido ao grande poder de aproximação das pessoas - aproximação esta promovida em ambiente virtual nas denominadas mídias sociais (facebook, whatsapp e outras) (GARCIA, 2013).

A mídia ${ }^{4}$ já vem sendo objeto de estudo por pesquisadores que a entendem como um mecanismo poderoso para a manipulação da população, mesmo em regimes ditos

\footnotetext{
${ }^{4}$ Frisa-se que, dada a multiplicidade de termos utilizados por diversos estudiosos do tema, utilizaremos como sinônimos - seja em citações ou diretamente - os termos mídia, media, mass media, mídia de massas e meios de comunicação em massa, todos no afã de delinear técnicas comunicacionais de grande abrangência. Anote-se desde já que, para fins do presente trabalho, em algumas situações se especificará os canais midiáticos (por exemplo, mídia televisiva etc.) ou grupo (por exemplo, velhas mídias, meios tradicionais de informação etc.), assim como também se utilizará o termo mídia como aparato informacional integrado (onde há a fusão dos meios tradicionais de informação [jornal impresso, rádio, televisão] e Internet [com as mídias sociais, como o 


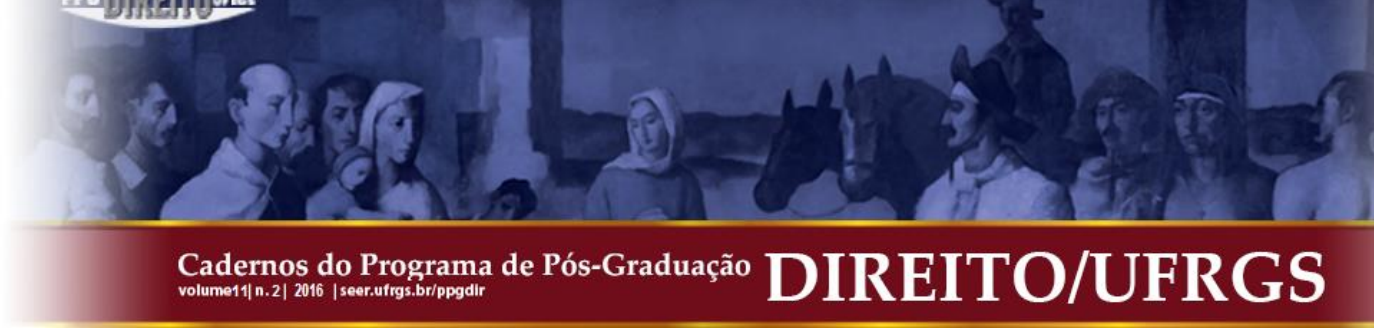

democráticos (CHOMSKY, 2013). Desse modo, indaga-se, reflexamente, seu poder de influência de direcionar a opinião pública acerca de um "direito penal desejado".

Posto isso, o problema central desta pesquisa é expresso nas seguintes frases: há um "direito penal desejado", expresso por internautas, no Brasil? Havendo, quais os aspectos mensuráveis desse "direito", e qual a influência dos veículos midiáticos para a formação desse discurso?

A suposição se dá pelo questionamento da mídia enquanto veículo parcial, cujo compromisso profissional está direcionado não apenas a transmitir a informação. Logo, ao contrário disso, adota-se, como hipótese, que a notícia veiculada pela mídia, a depender do discurso por ela tecido, contribui de forma determinante para a formação da opinião internalizada pelos internautas e, por conseguinte, para a composição de seus comentários acerca do "direito penal desejado".

Para a análise do texto (matérias jornalísticas online e comentários), a maneira de fazer a descrição do discurso (DIJK, 2010, p. 12) será trabalhada a partir da Análise Crítica do Discurso - inegavelmente uma análise social (FAIRCLOUGH, 2001).

\section{PERSPECTIVAS PUNITIVAS NO ATUAL CONTEXTO SOCIAL}

Hoje, na denominada modernidade líquida ${ }^{5}$, pós-modernidade, ${ }^{6}$ alta modernidade ou capitalismo tardio $^{7}$, dentre tantas outras designações equivalentes - termos a partir dos quais, em suma, tenta-se explicar teoricamente o momento social contemporâneo, a nível global -, o recrudescimento penal está em voga no discurso oficial pátrio (controle social

jornalismo interativo online etc.]). Todavia, a adjetivação do termo ou predicação permitirá a dissolução de qualquer ambiguidade terminológica.

${ }^{5}$ Segundo o autor, a presente sociedade caracteriza-se pela volatilidade e liquidez das relações pessoas e outras (BAUMAN, 2009). Sobre o que Bauman (2001) denominou por "modernidade líquida", no atual contexto social, os meios de comunicação, "[...] criam um mundo de imagens voláteis, na qual o modo de vida que sobressai é a individualização, que tem uma íntima ligação com a incerteza e segurança. Dessa forma, a vida na sociedade líquida configura-se como sendo cheia de armadilhas que, possui com um desdobramento, o medo" (SILVA; MENDES; ALVES, 2015, p. 257).

${ }^{6}$ Era das novas sociedades ocidentais, caracterizadas por "fortes abalos, vinculados à perda de referências, à desagregação dos moldes herdados do passado, ao enfraquecimento das certezas: a sociedade 'moderna' tende a dar lugar a uma nova sociedade que, ainda que se enraíze na modernidade, apresenta características dela diversas" (CHEVALLIER, 2009, p.13).

7 “O mundo moderno tardio — o mundo do que chamo de alta modernidade — é apocalíptico não porque se dirija inevitavelmente à calamidade, mas porque introduz riscos que gerações anteriores não tiveram que enfrentar" (GIDDENS, 2002, p. 11-12). 
institucionalizado), aparentemente amparado pelo clamor punitivo popular que se faz ouvir com bastante intensidade (controle social difuso) ${ }^{8}$.

Nesse sentido, interessante fenômeno para o qual chamamos a atenção, nessa perspectiva punitivista hodierna, é que como a história recente do País denota, há uma aparente influência da opinião pública, gerada e fomentada pujantemente pelos meios de comunicação em massa, no processo de criação de leis penais nas últimas décadas - assim como na sedimentação de um sistema penal mais recrudescido, em sua totalidade (controle social punitivo institucionalizado).

Como ensina Zaffaroni, a estrutura oferecida pelo poder punitivo inevitavelmente sofre influência de outras agências, as quais convencionou chamá-las de empresários morais (ou empreendedor moral $)^{9}$, que são direcionamentos para atuação criminógena em uma dada sociedade (ZAFFARONI et al., 2003, p. 45).

Uma das constatações que se pode alegar, dada a frequente incidência da mídia moderna no processo sistema penal, tanto direta quanto indiretamente, é que ela exerce um papel que vai além da mera função comunicativa (BATISTA, 2002, p. 254) havendo, no que Nilo Batista denominou de capitalismo tardio, uma verdadeira "executivização dessas agências de comunicação social do sistema penal" (BATISTA, 2002, p. 254). Nesse sentido, vários são os casos de incidência midiático-popular no processo legislativo criminal.

Traçando um parâmetro entre mass media e a legislação penal que vem se recrudescendo ultimamente legitimada pela opinião pública, vemos, entre alguns exemplos, que a lei dos crimes hediondos (Lei 8.072/1990), foi claramente motivada pelo sequestro do empresário Abílio Diniz, no final dos anos 80, amplamente explorado pelo jornalismo do País; a lei dos crimes hediondos (Lei 8.930/1994), nitidamente foi fomentada a partir do assassinato da atriz Daniela Perez, igualmente exacerbado pelos meios de comunicação; a lei de tortura (Lei 9.455/1997), a partir da forte repercussão jornalística de policiais matando pessoas na Favela Naval; também a Lei 9.677/98 e a Lei 9.695/98 foram criadas logo após o "escândalo dos remédios falsos" divulgados pela imprensa; inúmeras alterações punitivistas no que tange aos menores infratores foram desencadeadas a partir da exploração jornalística

\footnotetext{
${ }^{8} \mathrm{O}$ controle social pode ser compreendido como, tanto um poder "difuso (meios de massa, família, rumores, preconceitos, modas etc.) ou institucionalizado (escola, universidade, psicquiátrico, polícia, tribunais etc.)" (ZAFFARONI; PIERANGELI, 2008, p. 65).

9 Relacionados como os agentes de comunicação social, as agências políticas e outros (ZAFFARONI et al., 2003, p. 45).
} 
do "caso Champinha”, em 2003; o RDD (Regime Disciplinar Diferenciado) foi criado, em 2006, a partir da repercussão midiática dos ataques do PCC que culminaram em várias mortes de policiais; em 2008, após a absolvição do fazendeiro Vitalmiro Bastos de Moura, criou-se a lei que extirpou o protesto por novo júri; em 2012, as Leis 12.735 e Lei 12.737 (Leis dos Crimes Digitais) foram patentemente editadas após uma atriz da Rede Globo de Televisão ter fotos vazadas na Internet (GOMES, apud SOHSTEN, 2016, p. [S.I]).

No intuito de tentar compreender em números o atual momento de recrudescimento penal, uma pesquisa realizada pela $\mathrm{ALPEC}^{10}$ indica que, tomando por parâmetro a data de 1940 (edição do Código Penal vigente) até o fim da ditadura, em 1985, ao todo foram criadas 91 leis de conteúdo penal (média de 2,07 leis penais por ano). Por outro revés, tomado o período de março de 1985 até dezembro de 2011, foram editadas 111 novas leis com teor penal (média de 4,27 leis penais ao ano). Isso significa que, após a democratização, o País "criminalizou mais que o dobro em praticamente metade do tempo, em comparação com o período da ditadura militar. Tal constatação coloca em xeque a própria efetivação do regime democrático" (DAMOUS, apud TOMAZ JR, 2016, p. [S.I]).

Por outra senda, atentando-se agora para o recrudescimento penal fomentado pela opinião pública ${ }^{11}$ - a nosso ver, gerada em grande parte pela mídia nacional ${ }^{12}$-, em relação à jurisprudência nacional (além das práticas corriqueiras de aprisionamentos preventivos perpetrados pelo Poder do Judiciário e, enfim, da onda de encarceramento no geral) ${ }^{13}$, recentemente vimos que o Supremo Tribunal Federal - cuja função é também a de "guardião

\footnotetext{
${ }^{10}$ Asociación Latinoamericana de Derecho Penal y Criminología. Disponível em: $<$ http://www.inej.edu.ni/alpec/>. Acesso em: 15 ago. 2015.

${ }^{11}$ Em pesquisa de opinião realizada pelo Latinobarómetro, chegou-se à conclusão que no caso do Brasil, " $64,3 \%$ dos entrevistados disseram que o Poder Judiciário do País não pune. Além disso, também disseram que a sensação de impunidade para esse tipo de delito prepondera em todo canto do Brasil" (DI REZENDE, 2015, p. [S.I]). Segundo pesquisa feita pela Fundação Getúlio Vargas, $76 \%$ da população lamenta ser a lei penal pouco severa no País. "Para 39\% dos entrevistados, leis penais muito brandas são a principal causa da impunidade, enquanto $36 \%$ das pessoas acreditam que a corrupção na Polícia contribui para a impunidade generalizada" (PARA..., 2011, p. [S.I]). Em outra pesquisa, concluiu-se que a "sociedade brasileira quer maior rigor no combate ao crime. A avaliação consta no estudo Retrato da Sociedade Brasileira: Segurança Pública, da Confederação Nacional da Indústria (CNI) [...]. A pesquisa revela que $79 \%$ dos entrevistados defendem penas mais duras para reduzir a violência no país" (JINKINGS, 2011, p. [S.I]).

${ }^{12}$ Como mostra a pesquisa realizada pelo Senado Federal em 2007, a mídia contribui fortemente para formar a opinião pública sobre a criminalidade. Segundo a pesquisa, "a convivência com atos violentos, por boa parte da população, contribui para o crescimento da insatisfação nacional com a impunidade". Segundo a pesquisa, $86 \%$ dos entrevistados alegaram que a violência aumentou muito no último ano, nada obstante apenas $36 \%$ dos entrevistados alegarem que já foram vítimas de violência (2006) (BRASIL, 2007, p. 1-2).

${ }^{13}$ Segundo dados do Depen, $41 \%$ de toda população carcerária é formada por presos provisórios, sendo que, em levantamento feito pelo Judiciário do Rio de Janeiro, concluiu-se que $54 \%$ das prisões eram indevidas (DIAS, 2015, p. [S.I]).
} 
da Constituição" (Art. 102, CRFB) - vem adotando posicionamentos que restringem alguns direitos do réu, já consolidados constitucionalmente. Entre notáveis exemplos, cite-se o inédito caso de prisão de um parlamentar por crime afiançável e prescritível (o que viola frontalmente o Art. 53, §2 , Constituição da República Federativa do Brasil) (TAFFARELLO, 2016) e a recente interpretação constitucional de que o condenado em segunda instância deve cumprir a pena imediatamente, mesmo com a "presunção de inocência" igualmente sendo prevista na Constituição da República, no capítulo sobre Direitos e Garantias Fundamentais (Art. 5, LVII, Constituição da República Federativa do Brasil) (BRASIL, 1988).

Nesse último caso, como elucidação da influência da opinião pública sobre o judiciário, frisa-se que os discursos dos ministros do Supremo Tribunal Federal na sessão de julgamento versavam prevalentemente sobre a famigerada "impunidade" e supostas "benesses" em demasia no processo penal, em se tratando de recursos. Fulgido no discurso de um dos ministros, Luiz Fux asseverou que: "Se há algo inequívoco hoje e a sociedade não aceita [é] a presunção de inocência e a pessoa condenada que não para de recorrer" (PEREIRA; TELES, 2016, p. [S.I] $)^{14}$ - nada obstante os dados oficiais (Infopen) demonstrem que o país é um dos mais punitivistas do mundo (711.463 presos, no total), tendo o $3^{\circ}$ maior contingente de detentos do planeta, além de ser o $2^{\circ}$ que mais encarcera (136\% de 1995 a 2010) (BARROCAL, 2015, p. [S.I]).

Já empiricamente (no controle social institucionalizado ou não), também legitimadas pela psicologia popular (SANTOS, 2016, p. 2) - igualmente, a partir da reiterada utilização e exacerbação do medo e da insegurança por parte da mídia de massas -, as punições são ainda mais cruéis do que as previstas formalmente nas Leis Penais. Por exemplo, há "pena não legislada de morte" por todo o país (seis pessoas são mortas por dia pela polícia) (PAGNAN; TUROLLO, 2014), amplamente aceita pela população ${ }^{15}$; a tortura, que é considerada problema crônico nas prisões brasileiras (RIBEIRO, 2014), vem sendo igualmente avalizada

\footnotetext{
${ }^{14}$ Além disso, o Ministro Cezar Peluso, já em 2011 alegava que "o Judiciário não pode ouvir passivamente" as críticas da opinião pública. "É preciso expor [nosso trabalho] à opinião pública, e essa é uma tarefa que nem sempre o Judiciário consegue desempenhar, explicar o que faz, e não ouvir passivamente o que a opinião pública, mediante a mídia, pensa sobre o Judiciário" (PELUSO, 2011, p. [S.I]).

15 "Uma pesquisa realizada pelo Datafolha, divulgada hoje mostra que $43 \%$ da população paulista, diz que o policial que participa de grupos de extermínio fora de seu horário de trabalho para matar bandidos, não deveria ser punido. Essa é a verdade de um povo que tem medo e está esperando justiça, independente de onde venha" (FARIAS, 2012, p. [S.I]). "População comemora e faz cortejo após PM matar suspeitos de assalto no MA" (MADEIRO, 2016, p. [S.I]). "População defende policial que matou dupla de assaltantes" (MELLO, 2015, p. [S.I]). "Metade da população das grandes cidades brasileiras considera que 'bandido bom é bandido morto', conforme revelou pesquisa do Instituto Datafolha, divulgada nesta segunda-feira. Para especialistas consultados por Zero Hora, a resposta não chega a ser reveladora" (SCIREA, 2015, p. [S.I]).
} 


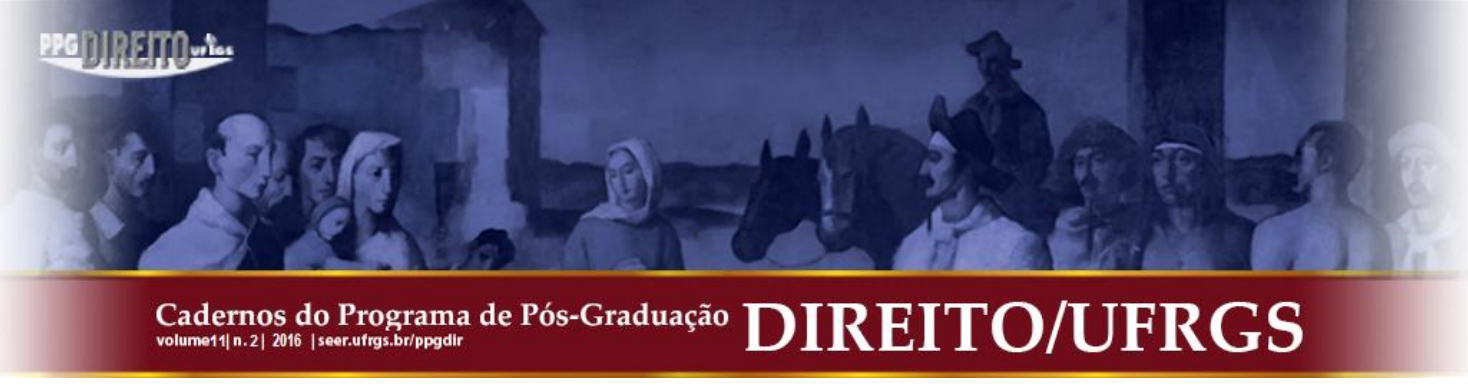

pela população brasileira ${ }^{16}$; penas vexatórias, julgamentos sumários e linchamentos etc. são rotineiros e também potencialmente legitimados pela opinião pública (o que poderá ser visualizado no capítulo da pesquisa), sendo o Brasil o país que mais promove linchamentos no mundo (AMPARO, 2015), numa média de um consumado ou tentado por dia (ROSA, 2015).

Nada obstante a visível inocuidade da crescente promulgação de leis punitivas, já demonstrada cientificamente ${ }^{17}$, na recente história nacional claramente percebe-se que o endurecimento penal novamente ganha corpo nos últimos anos (com fito aos precedentes históricos), tendo ampla acedência popular - seja por meio do controle social institucionalizado (legislativo, judiciário, polícia etc.) ou pela atuação do controle social difuso (não institucionalizada, como linchamentos, execuções sumárias etc.).

Acertadamente Maria Lúcia Karam aduz que, nos tempos atuais, passamos por uma "enganosa publicidade do sistema penal", que tem de inovador o "significativo reforço do distorcido, dramático e demonizador discurso da repressão penal" gerenciado pelo "eco advindo da intensificada divulgação pelos meios massivos de informação de condutas socialmente negativas ou conflituosas qualificadas como crimes" (KARAM, 2009, p. 22). Não se pode negar que, como disseram Zaffaroni e Pierangeli (2008, p.163), no estágio atual das punições "a luta está mais encarniçada do que nunca".

\section{O PROJETO DE NOVO CÓDIGO PENAL (PLS Nº 236/2012)}

Recentemente, está-se às vésperas do histórico momento da promulgação de nova legislação penal - Projeto de Lei (PLS 236/2012 - Novo Código Penal) de autoria de José

\footnotetext{
16 "Quase a metade dos brasileiros, 47,5\%, apoia que os suspeitos de crime sejam torturados em busca de provas pela Polícia. Este número está apontado na mais recente pesquisa do "Núcleo de Estudos sobre a Violência", da Universidade de São Paulo. Foram consultados mais de 4.000 brasileiros de todas as regiões do país. Esta pesquisa mostra que o apoio à violência e à tortura por parte da Polícia cresceu de 1999 até hoje. Em 1999 28,8\% dos brasileiros apoiavam as práticas de tortura da Polícia, número que hoje atingiu $47,5 \%$. A pesquisa mostra também que um terço dos consultados concorda com métodos como bater nos suspeitos, dar choques elétricos ou queimar partes do corpo, e também deixar a pessoa investigada sem comida e água" (VIEIRA, 2012, p. [S.I]). "Metade dos brasileiros aceita tortura de acusados [...]. O uso de algum tipo de violência é mais aceito para suspeitos de delitos como estupro (43,2\%), tráfico de drogas $(38,8 \%)$, sequestro $(36,2 \%)$, uso de drogas $(32,3 \%)$ e roubos $(32,1 \%)$. Esses suspeitos poderiam receber um pior tratamento durante a investigação policial, na opinião dos pesquisados. O levantamento mostra que quanto mais jovem o entrevistado, maior parece ser a tendência em apoiar o uso de práticas de tortura" (METADE..., 2012, p. [S.I]).

${ }^{17}$ Segundo pesquisa elaborada pelo Ministério da Justiça, por exemplo, após a entrada em vigor da Lei dos crimes Hediondos (Lei 8.072/1990) a "a população carcerária no Brasil saltou de 148 mil para 361 mil presos entre 1995 e 2005, mesmo período em que houve o crescimento de $143,91 \%$ nos índices de criminalidade" (VASCONCELLOS, 2016, p. [S.I.]).
} 


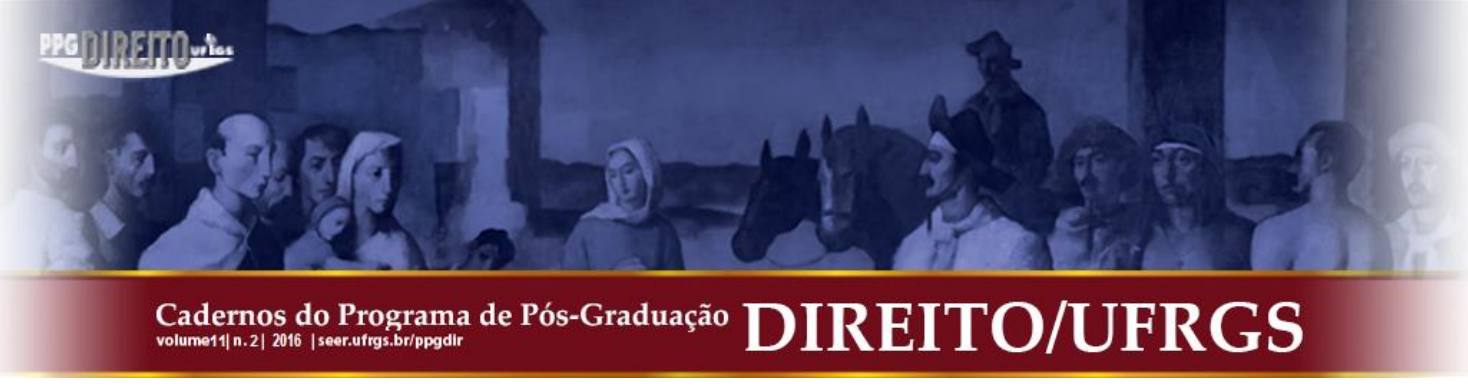

Sarney. Percebe-se de seu texto, igualmente, a presença marcante do viés punitivista a ser consagrado em forma de Lei.

Se comparado o PLS 236/2012 ao Código Penal atual (Decreto-Lei 3.688/41), em vigor desde $1^{\circ}$ de janeiro 1942, o referido Projeto de Lei possui previsões de punições mais austeras em vários tópicos. Dentre tantas alterações substanciais de recrudescimento penal, vê-se, por exemplo, que a punição dos crimes contra a vida tem a pena mínima expandida, em relação ao homicídio; há a tipificação do crime de terrorismo, expressamente baseado no direito penal do inimigo ${ }^{18}$; previsão de crimes contra o funcionamento das instituições públicas e dos serviços essenciais; o crime do chamado caixa dois; torna a corrupção crime hediondo; o estelionato adquire novas formas de aumento de pena; crimes contra a Administração Pública são exacerbados; crimes patrimoniais recebem penas mais duras. No âmbito empresarial prevê a responsabilidade criminal por atos de pessoa jurídica contra a administração pública (como a corrupção ativa, o contrabando, o descaminho, entre outros), a ordem econômica (como no cartel), e o sistema financeiro (como a lavagem de dinheiro e evasão de divisas) (BRASIL, 2016). ${ }^{19}$

Segundo Alaor Leite, o discurso dos reformadores insiste em "vociferar sua brasilidade" e lamentavelmente deixa de "lançar os olhos sobre a história do direito penal brasileiro". "O reformador também não parece comovido pela realidade carcerária brasileira, já que compreende a pena como um ato de "vingança social'”, (LEITE, 2015, p. [S.I]).

Além da já evidenciada influência popular-midiática sobre o processo criminalizante na recente história penal pátria, destaca-se uma nova peculiaridade no que tange à tessitura do Novo Código Penal, em trâmite no Congresso Nacional: o novo aparato integrado de media, consistente numa ponte entre as novas e velhas tecnologias (fusão da Internet [mídias sociais] e dos tradicionais media), a partir do qual se tornou possível uma interação mediada, onde

\footnotetext{
${ }^{18}$ Segundo justificação do PL 236/2012 (gabinete senador Sérgio Souza), decidiu a CCJ (Senado) que, "Em conformidade com a Criminologia Contemporânea, nesses casos, o direito penal deve antecipar a tutela penal, mesmo que a pena aplicada seja a intensa e talvez, desproporcional. o Direito penal do inimigo procura predominantemente a eliminação de um perigo contra a sociedade, que deve ser eliminado pelo maior tempo possível, impedindo que o sujeito pratique crimes fora do cárcere. Enquanto ele estiver preso, haverá prevenção do delito, em relação a delitos que poderiam ser cometidos fora do presídio. Por essas razões, conclamamos o apoio dos insignes Parlamentares para aprovação desta Emenda" (BRASIL, 2016, p. 2-3).

${ }^{19} \mathrm{Em}$ um dos movimentos de recrudescimento penal mais importante, a Proposta de Emenda à Constituição (PEC 33/2012), que advoga a redução da maioridade penal dos 18 para os 16 anos, já aprovado na Câmara dos Deputados, atualmente está em tramitação no Senado Federal. Interessante notar que, dos 34 comentários acostados à página do Senado Federal que versava sobre o tema, 27 comentários apóiam a PEC, enquanto 7 não apóiam (BRASIL, 2015).
} 


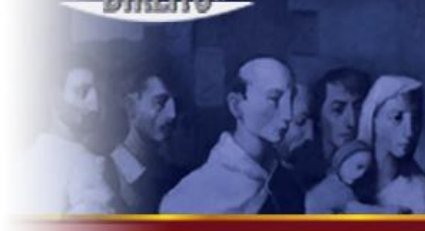

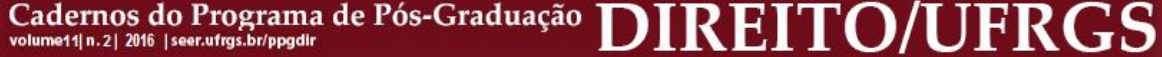

povo e autoridades coexistem no mesmo âmbito (CARDOSO, 2015). Em suma, dá-se "poder às vozes silenciosas dos que reclamam autodeterminação e justiça social" (CARDOSO, 2015, p. 6).

Sobre o referenciado Projeto de Lei Penal, vê-se a marcante presença das mídias sociais - ou outras plataformas que permitem a inserção de comentários (interação) sobre determinado assunto (como a plataforma de comentários em notícias online, que também podem ser compartilhadas virtualmente) -, atuando de forma a conduzir o legislador a um “direito penal desejado". Apesar de não ser propriamente algo inédito (a influência externa), chama atenção a expressa deliberação parlamentar de aceitar o clamor público mediado, advindo da Internet (ao invés de utilizar-se de debates públicos, como fóruns, audiências públicas etc., enfim, de espaços destinados ao amplo debate e discussão).

Nesse sentido, o presidente da CCJ, Eunício Oliveira (PMDB-CE), por exemplo, alega ser necessário uma "sintonia entre Parlamento e opinião pública", disponibilizando até mesmo um e-mail aos cidadãos para o envio de críticas e sugestões sobre o novo Código Penal (PL n ${ }^{\circ}$ 136/2012) (CHAGAS, 2012, p. [S.I]). Segundo o senador Pedro Taques (PDT-MT), o debate será conduzido pelo Congresso Nacional "levando em consideração as sugestões e opiniões da sociedade, seja pela internet ou em audiências públicas" (CHAGAS, 2012, p. [S.I]). Em poucas horas, as redes sociais do referido senador foi tomada por comentários em forma de sugestões legislativas.

Em suma, o que se apreende desse afã do legislativo é uma reiterada tentativa parlamentar de recrudescimento punitivo, numa espécie de truísmo da representatividade democrática - posto que aparentemente há legitimação popular para tanto, como indicam várias recentes pesquisas nacionais ${ }^{20}$ - nada obstante a "sobrecarga política interativa" e "o

\footnotetext{
${ }^{20}$ A pesquisa "Retratos da Sociedade Brasileira: segurança pública", realizada pela CNI/Ibope, aponta que "79\% dos entrevistados acreditam que penas mais rigorosas podem reduzir a criminalidade. Entre os entrevistados, $46 \%$ defendem a pena de morte ( $31 \%$ defendem totalmente e $15 \%$, em parte). A prisão perpétua é também aceita por $69 \%$ dos entrevistados. A pesquisa também aponta que $86 \%$ dos entrevistados aceitam a redução da maioridade penal" (ALCÂNTARA, 2016, p. [S.I]). Já o Instituto Paraná Pesquisas, chegou à conclusão de que " $90,4 \%$ dos entrevistados são favoráveis à responsabilização criminal de adolescentes, apenas 8,3\% declararam ser contra. Para $64 \%$ dos entrevistados, a redução da maioridade contribuiria para reduzir a violência. A pesquisa mostra ainda que $55 \%$ dos consultados avaliaram que a proposta deva valer para todos os tipos de crimes, mesmo delitos considerados mais leves" (ANÍBAL, 2016, p. [S.I]).
} 


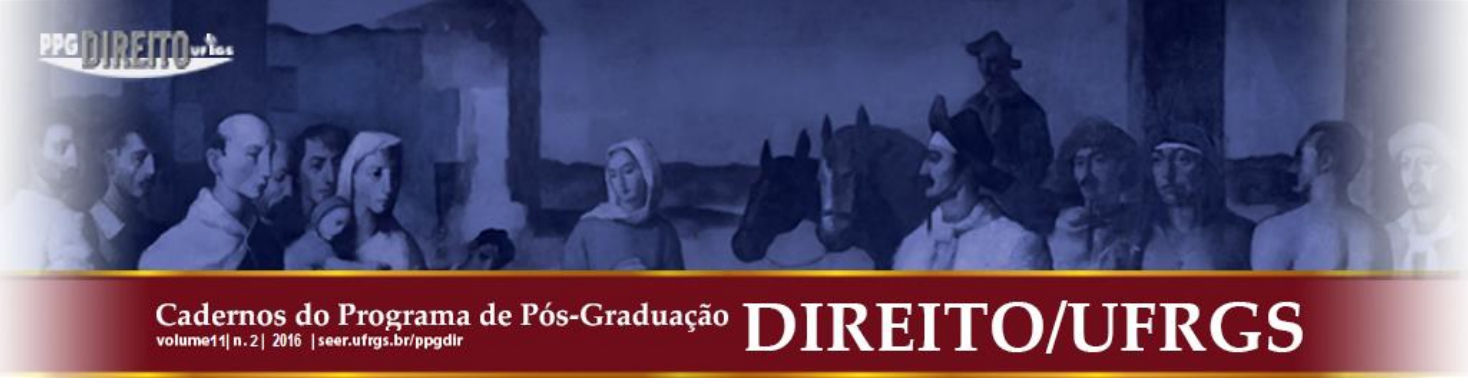

uso demagógico das redes sociais [...] para ir ao encontro do que o povo queria" (MALINI, apud ARAÚJO, 2015, p. [S.I]). ${ }^{21}$

Assim, como forma de tentar desvendar aspectos desse "direito penal desejado" pelos internautas, e entendendo que opinião pública e a opinião publicada são contíguas $^{22}$, passaremos à pesquisa, sempre tendo em vista a atuação midiática contemporânea como empreendedora moral no processo criminalizante.

\section{PROCEDIMENTOS DE ANÁLISE}

A presente pesquisa, em multimétodo (mescla dados quantitativos e qualitativos) (FREITAS et al., 2000, p. 105), terá como finalidade analisar qual é o "direito penal desejado" por internautas em comentários tecidos a jornal online (na plataforma comentários de mídia social). Trata-se de um estudo com metodologia diferenciada, posto tratar-se de uma espécie de survey (levantamento) (CRESWELL, 2014, p. 178-183) onde há a espontaneidade na geração dos dados - portanto, com ausência de questionário fixo -, se valendo o pesquisador das opiniões expressadas randomicamente por internautas.

O levantamento a seguir apresentado tem como propósito o aspecto explanatório (testar teorias e relações causais) e descritivo (buscar opiniões manifestas e distribuição de alguns fenômenos presentes em dada população - no caso, os internautas) (PINSONNEAULT; KRAEMER, apud FREITAS et al., 2000, p. 106), sendo a representatividade da população feita por amostragem.

Nesse sentido, o presente capítulo trabalha o discurso (informativo ou opinativo) de um segmento da mídia online brasileira, num primeiro momento, sobre um linchamento ocorrido

\footnotetext{
${ }^{21}$ A deputada Mara Gabrilli (PSDB-SP) e o deputado Paulo Foletto (PSB-ES), por exemplo - como comprovam publicações em suas redes sociais, radicalmente mudaram de voto em vinte e quatro horas. "Teve um caso curioso aqui no Espírito Santo em que um deputado do PSB gravou um vídeo, se posicionando contra a redução da maioridade penal, e no dia seguinte gravou outro vídeo, explicando porque votou a favor. Nesse meio tempo, ele foi alvo de uma reação muito violenta dos seus seguidores. É um exemplo do que muitos deputados viveram, tendo de responder aos seus eleitorados, algo que fez muitos deles mudarem de opinião" (MALINI, apud ARAÚJO, 2015, p. [S.I]).

22 “É preciso considerar que os meios de meios de comunicação de massa não são apenas 'espaço para debate'; se o fossem, representariam totalmente a opinião pública - não é o caso. Eles também são 'atores', com interesses e demandas como qualquer outro ator social envolvido no debate público. Sendo assim, meios de comunicação são parcialmente capazes de representar a opinião pública, porém, como também são agentes interessados, geram uma distinção entre opinião pública e opinião publicada. Em um sistema comercial de mídia, como o brasileiro, jornais que se afastam da opinião majoritária da sociedade tendem a perder espaço no debate público. Portanto, a mídia precisa equilibrar a função de espaço para debate com seus próprios interesses" (CERVI, 2009, p. [S.I]).
} 


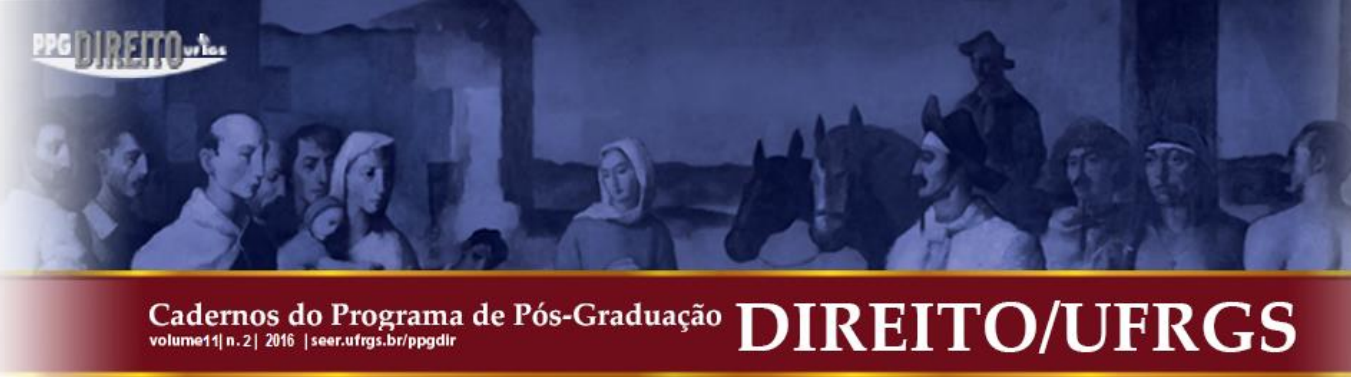

em São Luís/MA, no dia 6 de julho de 2015. Além disso, investiga-se a opinião dos internautas, com base nos comentários publicados na área destinada a inserção de opiniões, sobre o fato divulgado como notícia por fontes jornalísticas online (mídia social). Ainda, se esse discurso influenciou tais comentários e, consequente, quais são os aspectos desse possível "direito penal desejado" em rede.

A seleção da fonte (material de análise) dá-se, principalmente, almejando trabalhar com um jornal online influente, e que tenha um público-alvo popular. Assim, a presente análise tem como locus o jornal online Extra, pertencente ao Grupo Globo, sendo o material jornalístico mais lido entre os internautas de todo o país (TAVARES, 2014). Com 2,7 milhões de leitores semanalmente - o que a classifica como plataforma online de jornal mais acessada - é "símbolo do jornalismo popular", tendo "foco no público classe média, a quem conhece como ninguém” (NASCIMENTO, 2015, p. [S.I]). ${ }^{23}$

Sobre o lapso temporal de análise, foram selecionadas todas as matérias que versavam sobre o caso, ainda que indiretamente, assim como todos os comentários de internautas a elas anexados. Ao todo, vinte matérias foram publicadas pelo Extra/Globo, num período de nove dias $(07 / 07 / 2015$ a 15/07/2015), e 1817 comentários foram gerados.

\subsection{A Descrição do Discurso}

A complexidade social contemporânea passa a demandar estudo multidisciplinar.

[...] um empreendimento será interdisciplinar todas as vezes em que ele conseguir incorporar os resultados de várias especialidades, que tomar de empréstimo a outras disciplinas certos instrumentos e técnicas metodológicos, fazendo uso dos esquemas conceituais e das análises que se encontram nos diversos ramos do saber, a fim de fazê-los integrarem e convergirem, depois de terem sido comparados e julgados. Donde podermos dizer que o papel específico da atividade interdisciplinar consiste, primordialmente, em lançar uma ponte para ligar as fronteiras que haviam sido estabelecidas anteriormente entre as disciplinas (JAPIASSU, 1976, p. 75).

\footnotetext{
${ }^{23}$ Para grande número de leitores dos jornais de maior circulação nacional, notadamente "Folha de São Paulo", "O Estado de São Paulo" e "O Globo", conforme venho observando sistematicamente, geralmente a leitura desse tipo de notícia [crimes violentos] não é alvo de maior interesse, e poucas vezes é priorizada, sendo quase sempre marginalizada. Já os leitores dos jornais considerados "populares", como "O Dia", mantêm com as notícias sobre crime, via de regra, uma outra relação, de maior interesse. Essas notícias são priorizadas pelos próprios editores dos jornais: exemplo disso são as capas de "O Dia", em que, salvo raras exceções, aparecem fotos ou manchetes destacando as reportagens sobre crime (MENDES, 2005, p. 77).
} 


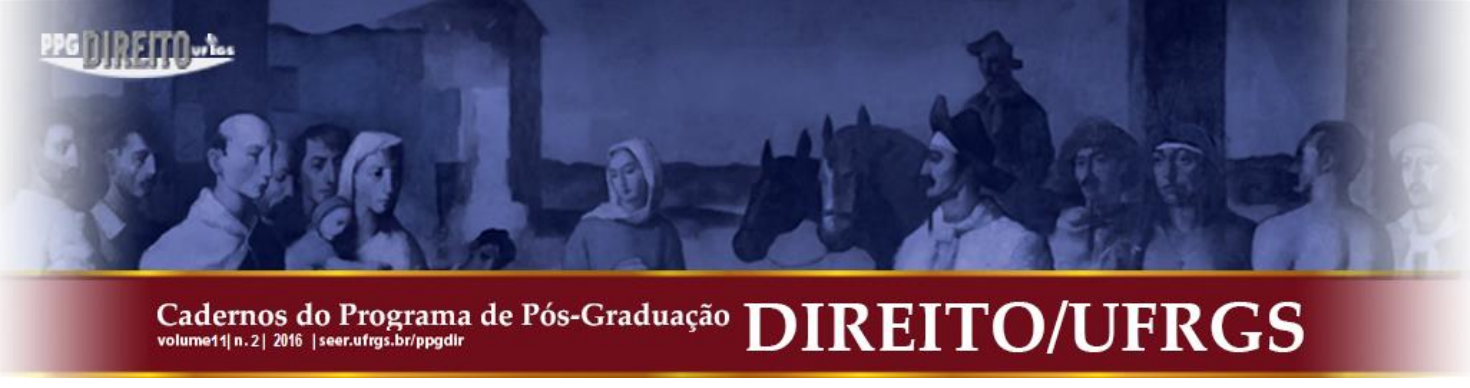

Ademais, de certa forma seguindo as orientações de Salo de Carvalho, que ensina que as tendências atuais da criminologia afastaram o foco central de debate a antigos objetos de análise: "crime, criminoso, reação social, instituições de controle, poder político e econômico" e insere a investigação sobre "a forma da linguagem da criminalização e do controle" (CARVALHO, 2015, p. 77). A análise do discurso é a maneira mais apropriada para os fins da proposta de trabalho (descrição do discurso). Ainda, muitos pesquisadores reconhecem a necessidade de perfilhar as mudanças de processos sociais e culturais como decorrentes de mudanças no uso linguístico (discurso como prática social) (FAIRCLOUGH, 2001, p. 19).

Desse modo, apesar de não ser propriamente um método de pesquisa - posto não haver um método específico de análise de discurso - nada impede que as abordagens por pesquisas de discurso sejam denominadas por maneiras de fazer a análise ou a descrição de discurso (VAN DIJK, 2010, p. 12). ${ }^{24}$

Desse modo, optamos pela Análise Crítica do Discurso como técnica de descrição do discurso - ou maneira de fazer análise -, de forma a elucidar o fenômeno do "direito penal desejado", e em termos gerais, as próprias mudanças sociais (FAIRCLOUGH, 2001).

\subsection{Os Modos de Operação da Ideologia}

Para o intuito a que se destina a pesquisa - a busca de aspectos do "direito penal desejado" a partir de comentários de mídias sociais -, optamos trabalhar os modos de operação da ideologia, a partir de Thompson (2002).

Para Thompson (2002, p. 88-89), ideologia se apresenta como "maneiras em que o significado mobilizado pelas formas simbólicas serve para estabelecer e sustentar as relações de dominação". Como visto, por formas simbólicas, Thompson se refere a "uma gama de ações e linguagens, imagens e textos que são produzidos por sujeitos e reconhecidos por eles e por outros como construções significativas" (2002, p. 89).

Segundo o supracitado autor (THOMPSON, 2002, p. 90), de inúmeras maneiras o significado pode servir para manter relações de dominação, e somente se pode responder a

\footnotetext{
${ }^{24}$ A principal razão é que os ECD [estudos críticos do discurso] não são, como frequentemente se presume especialmente nas ciências sociais -, um método de análise do discurso. Não existe esse tipo de método. Os ECD usam qualquer método que seja relevante para os objetivos dos seus projetos de pesquisa e tais métodos são, em grande parte, aqueles utilizados em estudos de discurso em geral (VAN DIJK, 2010, p. 10).
} 


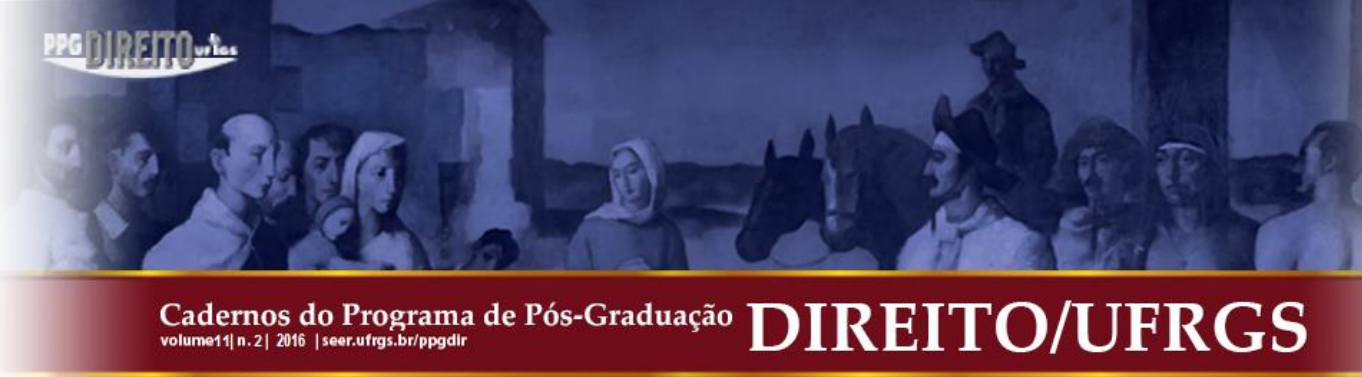

esta pergunta adequadamente se prestar-se atenção, cuidadosamente, à interação de poder e significado nas atuais circunstâncias da vida social. Thompson (2002, p. 91) propõe elucidar modos gerais de operação da ideologia no processo discursivo, assim como indicar formas de como se vincular a estratégias de construção simbólica. Vejamos abaixo:

\begin{tabular}{|c|c|}
\hline MODOS GERAIS & ALGUMAS ESTRATÉGIAS TÍPICAS \\
\hline $\begin{array}{l}\text { Legitimação } \\
\text { Relações de dominação são } \\
\text { representadas como legítimas. }\end{array}$ & $\begin{array}{l}\text { Racionalização: uma cadeia de raciocínio procura justificar um } \\
\text { conjunto de relações. } \\
\text { Universalização: interesses específicos são apresentados como } \\
\text { interesses gerais. } \\
\text { Narrativização: exigências de legitimação inseridas em histórias } \\
\text { do passado que legitimam o presente. }\end{array}$ \\
\hline $\begin{array}{l}\text { Dissimulação } \\
\text { Relações de dominação são ocultas, } \\
\text { negadas ou obscurecidas. }\end{array}$ & $\begin{array}{l}\text { Deslocamento: deslocamento contextual de termos e expressões. } \\
\text { Eufemização: valorização positiva de instituições, ações ou } \\
\text { relações. } \\
\text { Tropo: sinédoque, metonímia, metáfora. }\end{array}$ \\
\hline $\begin{array}{l}\text { Unificação } \\
\text { Construção simbólica de identidade } \\
\text { coletiva. }\end{array}$ & $\begin{array}{l}\text { Estandartização: um referencial padrão proposto como } \\
\text { fundamento partilhado. } \\
\text { Simbolização da unidade: construção de símbolos de unidade e } \\
\text { identificação coletiva. }\end{array}$ \\
\hline $\begin{array}{l}\text { Fragmentação } \\
\text { Segmentação de indivíduos e grupos } \\
\text { que possam representar ameaça ao } \\
\text { grupo dominante. }\end{array}$ & $\begin{array}{l}\text { Diferenciação: ênfase em características que desunem e impedem } \\
\text { a constituição de desafio efetivo. } \\
\text { Expurgo do outro: construção simbólica de um inimigo. }\end{array}$ \\
\hline $\begin{array}{l}\text { Reificação } \\
\text { Retração de uma situação transitória } \\
\text { como permanente e natural. }\end{array}$ & $\begin{array}{l}\text { Naturalização: criação social e histórica tratada como } \\
\text { acontecimento natural. } \\
\text { Eternalização: fenômenos sócio-históricos como permanentes. } \\
\text { Nominalização/passivação: concentração da atenção em certos } \\
\text { temas em detrimento de outros, com apagamento de atores e } \\
\text { ações. }\end{array}$ \\
\hline
\end{tabular}

Tabela 1: Modos de operação da ideologia em Thompson (2002).

Fonte: (COLARES, 2014, p. 130)

Virgínia Colares (2014, p. 130) ensina que, para trabalhar com os modos de operação da ideologia, faz-se necessário observar os movimentos do exercício da linguagem que a "afastam de um sentido mínimo", como a ironia, por exemplo, que disfarça acusações, sendo "uma maneira aparentemente mais leve de dizer algo que não se deve dizer diretamente ou frente a frente", assim como as metáforas, hipérbole e o eufemismo (2014, p. 130). 


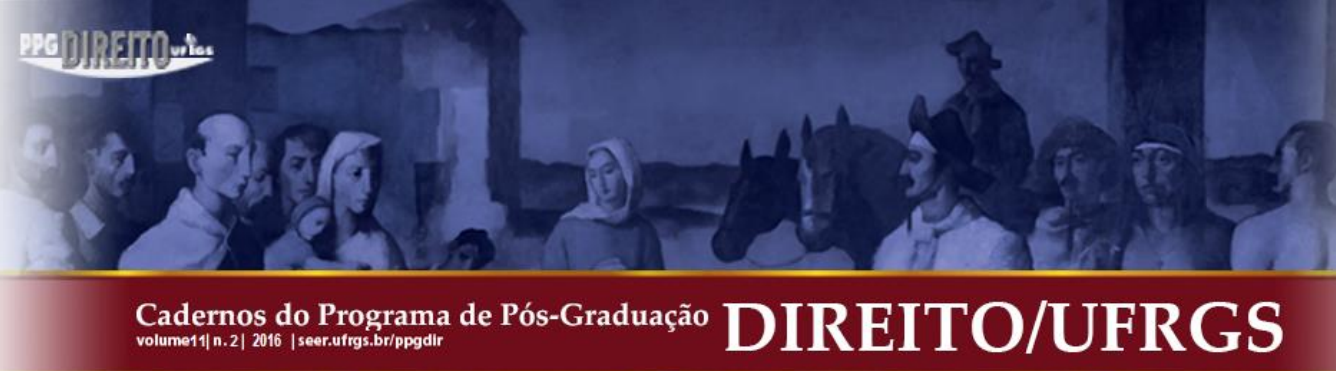

\section{O CASO DO LINCHAMENTO NO MARANHÃO}

As matérias especificamente analisadas versam sobre o caso de um homem, neste item reconhecido pelas siglas C.P.S., e de um menor não identificado pelo nome, ambos, vítimas de "justiçamento" (linchamento) ocorrido no bairro Jardim São Cristóvão, São Luís, capital do Maranhão.

Segundo noticiado em múltiplas matérias sobre o caso, tratava-se de uma malograda tentativa de assalto (roubo) a um estabelecimento comercial (bar) no qual as vítimas do linchamento invadiram, de posse de um revólver. Ainda, segundo relatos emanados do referido jornal, após a tentativa frustrada, populares amarraram os supostos assaltantes ao poste de iluminação pública e violentamente os agrediram com socos, pontapés, garrafadas, pedradas, pauladas e outros objetos. C.P.S. faleceu no local do linchamento. O menor foi resgatado com vida pela polícia militar local.

\subsection{Matérias e Comentários}

Como pode ser verificado no gráfico abaixo (Gráfico 1), há uma sequência cronológica de publicações. Verifica-se também a quantidade de comentários que em cada uma das matérias foi gerada, assim como a significante disparidade quantitativa de comentários inseridos na plataforma, se comparadas entre si. Vejamos:

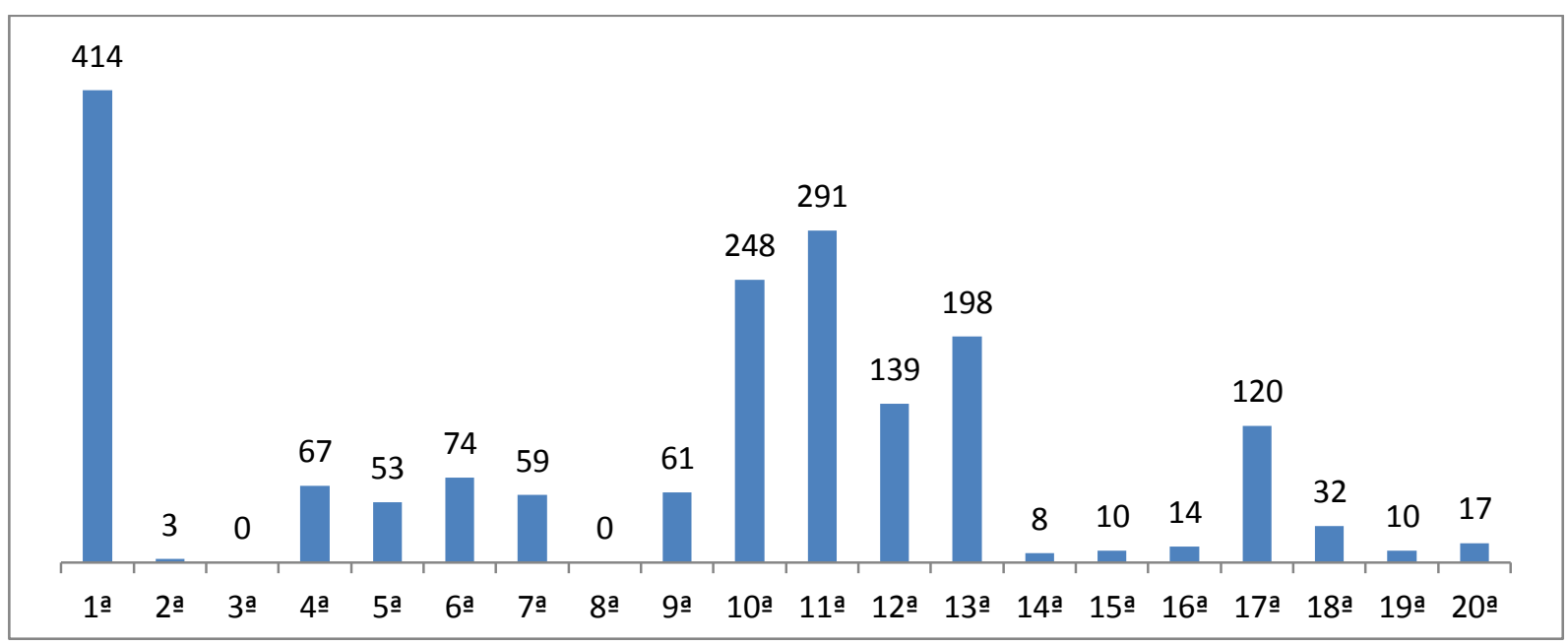

Gráfico 1 - Quantidade de comentários gerados na página do jornal Extra sobre o Caso do linchamento no MA. Fonte: Elaborado pelo pesquisador. 


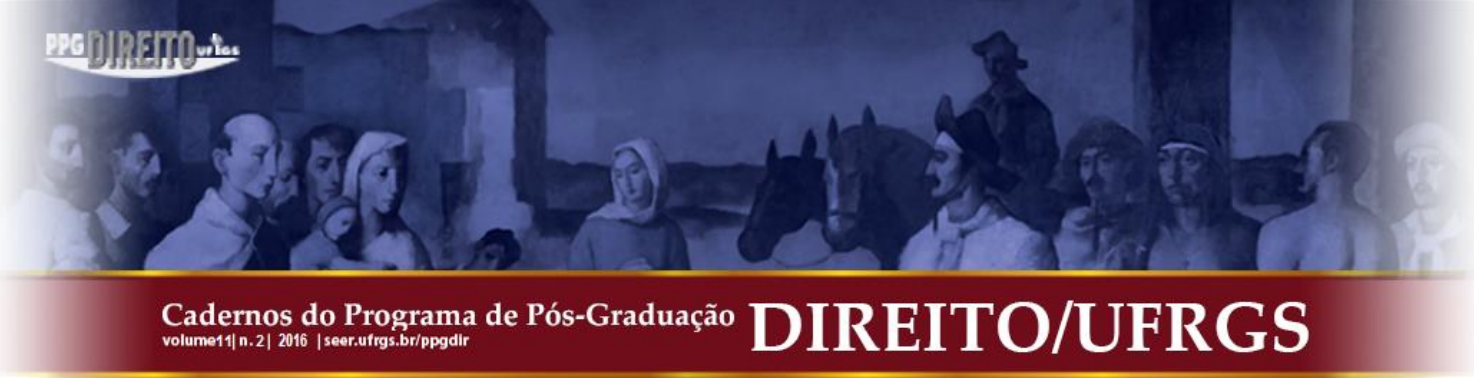

nesta última matéria, foi possível notar certa insatisfação dos internautas leitores, tendo dois dos três comentários questionado: “Cadê meu comentário?" (EXTRA, 2015, p. [S.I]). ${ }^{25}$ Sobre isso, vejamos o que aduz o Termo de uso da plataforma de comentários do Extra/Globo:

1.3. Os Comentários feitos por Você serão identificados como de sua autoria, sendo proibido o anonimato. Os Comentários serão publicados pela INFOGLOBO sem qualquer edição ou prévia moderação.

1.4. Cada Produto da INFOGLOBO poderá definir, a seu exclusivo critério, se poderão ser feitos Comentários sobre o conteúdo publicado, bem como o prazo em que a Plataforma ficará aberta para Comentários (EXTRA, 2015, p. [S.I]).

Feitas as ressalvas, vamos à análise qualitativa dos comentários, a fim de desvelar a legitimação ou não do evento pelos leitores, e, por conseguinte, analisar qual seria a punição desejada em casos similares ao relatado nas matérias.

\subsection{Panorama Geral dos Comentários}

No panorama geral, do total de 1817 comentários tecidos nas vinte matérias publicadas pelo Extra/Globo concernente ao acontecimento (linchamento), nota-se que 1126 comentários de algum modo legitimavam o linchamento (parabenizando, expressando satisfação explícita, apoiando e incentivando a prática, ou sendo conivente), enquanto 395 faziam o contrário, criticando o evento, e apenas 296 comentários eram controversos ou não se posicionavam (explicitamente) quanto à legitimação ou não da ação punitiva extraoficial. Nesse sentido, vejamos:

\footnotetext{
${ }^{25}$ Curiosamente, a matéria de número 3 era justamente a intitulada de Internautas divergem sobre linchamento de assaltante no Maranhão, publicada no dia 08/07/2015 (segundo dia de publicações), onde o jornal declara que "Os internautas bateram o martelo: a maioria aprova o linchamento de dois assaltantes na segunda-feira, em São Luís, Maranhão” (EXTRA, 2015, p. [S.I]).
} 


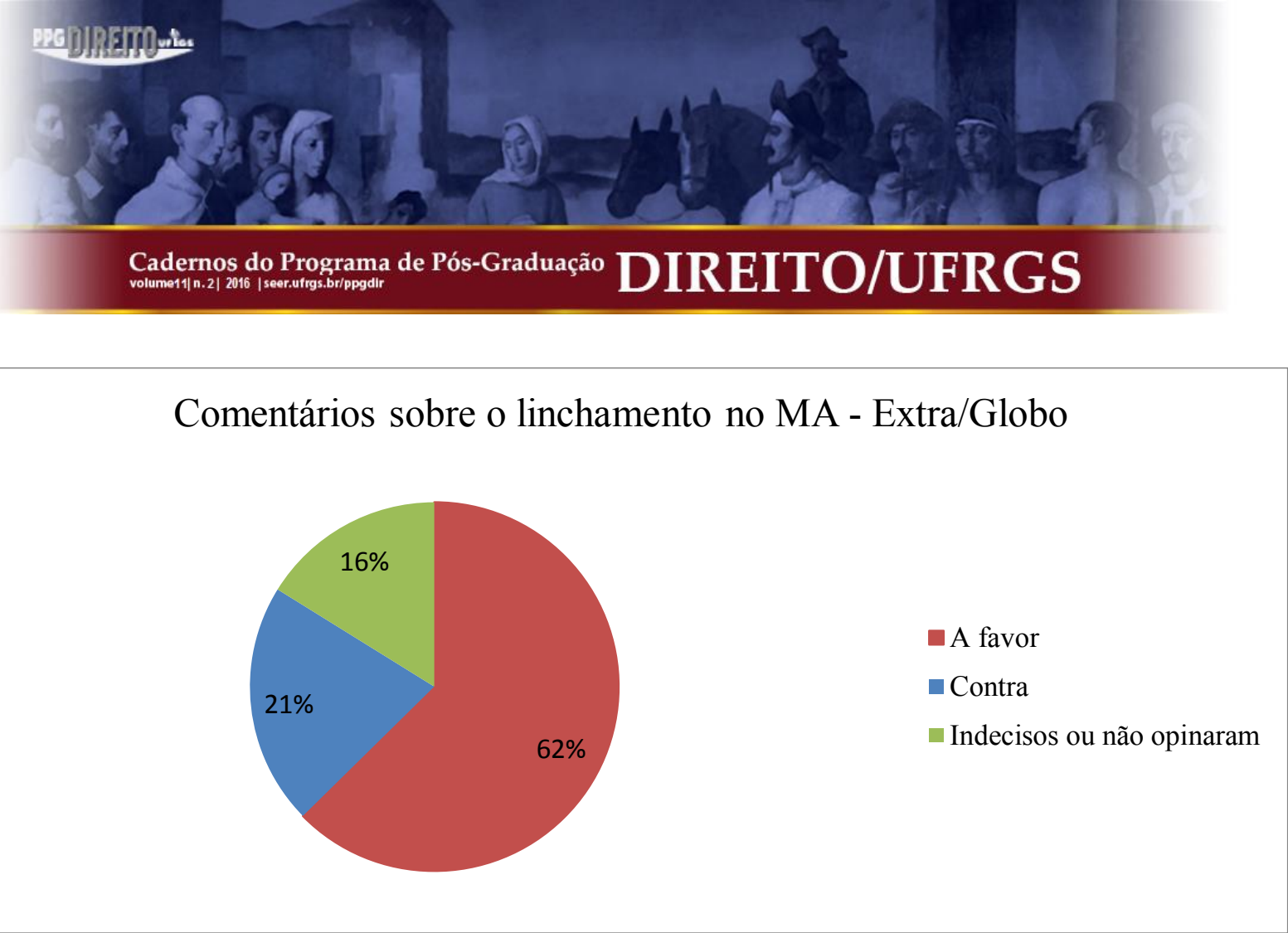

Figura 1 - Mapeamento geral dos comentários de internautas sobre o caso MA no Extra (Globo), porcentagem. Fonte: Elaborado pelo pesquisador.

Por outro lado, se levar-se em conta somente os comentários que possuíam opinião expressada sobre o evento (implícita ou explicitamente), o gráfico fica ainda mais expressivo. Vejamos:

\section{Comentários sobre o linchamento no MA - Extra/Globo}

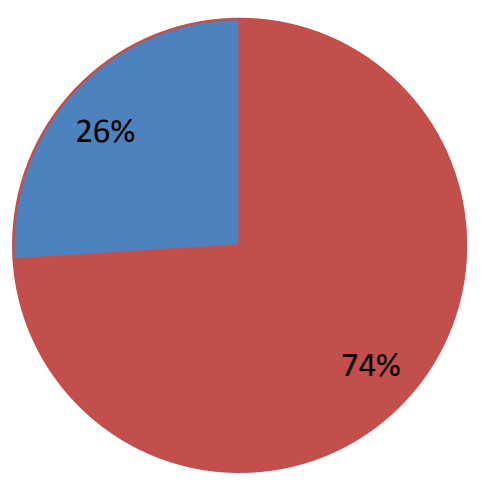

A favor

Contra

Figura 2 - Mapeamento geral dos comentários de internautas sobre o caso MA no Extra (Globo) em porcentagem, excluídos os indecisos ou que não opinaram.

Fonte: Elaborado pelo pesquisador.

Assim, em termos genéricos, é possível concluir que a pesquisa demostra ser $74 \%$ dos internautas favoráveis ao "justiçamento" público, ao passo que somente $26 \%$ mostram alguma 


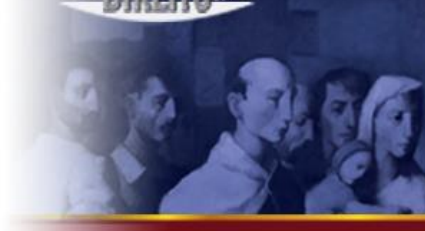

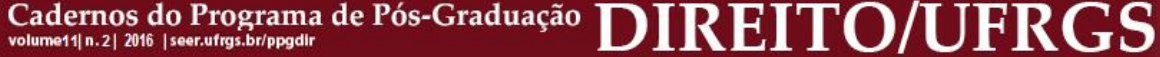

resistência ao linchamento, discursivamente. ${ }^{26}$ Dado isso, pode-se dizer que há um "direito penal desejado" por internautas nas mídias sociais. Porém, até então não nos aproximamos do conteúdo desses comentários. Afinal, quais são os principais aspectos desse "direito penal"?

\subsection{O "Direito Penal Desejado" nos Comentários}

Em termos gerais, a pesquisa vislumbrou um discurso majoritariamente voltado à repressão, ao recrudescimento penal e ao julgamento imediatista, a partir internautas leitores do jornal online Extra/Globo. O discurso expressado é o de legitimação do "justiçamento" como o perpetrado por populares às vitimas do caso do linchamento do Maranhão -, concebendo como acertada a aplicação da pena de morte àqueles surpreendidos em conduta considerada criminosa.

Os dados discursivos encontrados na pesquisa indicam que a sensação, na massiva maioria, é a de que o País passa por um inaudito momento de impunidade, insegurança, medo e corrupção, o que justifica a atuação dos julgamentos populares cruéis.

Voltando vistas novamente sobre os discursos expressos (comentários) que legitimavam o julgamento popular (74\%), interessante destacar que, se tomados em sua totalidade, novos dados podem ser avultados. Assim, vejamos que, a partir desse novo corte, conclui-se que cerca de $40 \%$ desses comentários apresentavam-se na forma do que denominamos por autoritários: a) adágios, sentenças arrogantes e cabais sobre determinada solução penal para o caso em comento (ou, virtualmente, em situações semelhantes), como "Bandido bom é bandido morto..." e "Tá com pena, leva pra casa..." (BOECHAT, 2015, p. [S.I]); b) aplausos, incentivos, lamentos por não ter-se podido participar do "justiçamento", como "BOAAAA, tem que passar FOOOGO, cadeia esta sendo Faculdade de bandido, qdo sai de lá, sai PIOR, então é FOOOOOGO nesses micróbios. PARABÉNS ao Povo Maranhense!” [sic] e “Que

\footnotetext{
${ }^{26}$ Inegavelmente colaborando para corroborar a fiabilidade dos dados até então obtidos na presente pesquisa, interessante parâmetro (tendo em vista a porcentagem de comentários prós e contra) pode ser visualizado em duas outras pesquisas, ambas feitas durante o mesmo período em que foi realizado o presente levantamento da opinião de internautas. Nesse sentido, o jornal $O$ Estado promoveu uma pesquisa de opinião entre internautas, lançando a seguinte pergunta: "Você é contra ou a favor da população 'fazer justiça' com as próprias mãos?". Foram levantadas as respostas emitidas de quarta-feira ( 8 de julho) até segunda-feira (13 de julho). $73,25 \%$ eram favoráveis ao linchamento, contra 26,75\% não favoráveis (ENQUETE..., 2015, p. [S.I]). Igualmente, o próprio jornal Extra promoveu o levantamento da opinião dos internautas utentes de uma de suas próprias mídias sociais (Facebook) no dia 8 de julho de 2015 (um dia após a publicação da primeira matéria sobre o citado linchamento). O jornal percebeu - coincidentemente, também a partir de 1817 comentários -, que $71 \%$ dos internautas apoiavam o fatídico evento ("justiçamento") (REDAÇ̃̃O, 2015).
} 


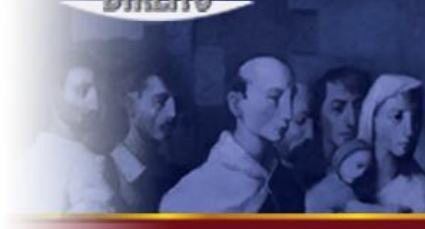

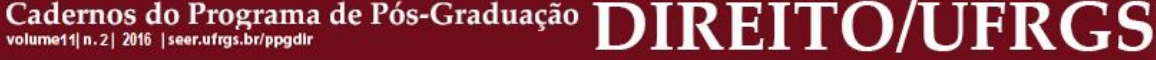

pena... pena eu não ter dado nenhum chute!!!” (BOECHAT, 2015, p. [S.I]); e, por fim, c) chacotas, sarcasmo e ironia, como "AHHHHHH SE A MODA PEGA!!! ESTOU MORRENDO DE PENA! KKKKKKKKKKKKKKKKKKKKKKKKK” [sic] (BOECHAT, 2015, p. [S.I]).

De certa forma, tal verificação corrobora com estudos de Theodor Adorno (2016), assim como nos remete ao que José Leon Crochik (2008) disse sobre essa mesma personalidade autoritária $^{27}$ :

\begin{abstract}
Além de propenso ao autoritarismo, o homem contemporâneo é dotado de frieza, quase não é mais capaz de identificação, de amar o outro, de ter experiências. Essas características são atribuídas pelo autor também à fragilidade da formação do eu, devida, por sua vez, quer à organização racional da sociedade que pode prescindir do pensamento individual, quer à ameaça existente de ser deixado de lado, caso não se siga o que todos seguem (CROCHIK, 2008, p. 303).
\end{abstract}

Os outros $60 \%$ eram majoritariamente justificações aparentes (como também convencionamos denominar), cujas opiniões se arrimavam nas mais diversas alegações: a) a justificação de que o "justiçamento" é legitimado pela suposta impunidade do sistema penal brasileiro (judiciário, leis etc.), tido como inoperante, como pode ser visto no comentário: "Estas situacoes lamentaveis vao para a conta do judiciario brasileiro e das policias que nao cumprem o seu papel. A populacao nao acredita mais em justica e acaba fazendo justica com as proprias maos" [sic] (BOECHAT, 2015, p. [S.I]); b) justificado pela suposta crescente delinquência criminal, rotineiramente vista em ascensão, como "Já estamos fartos de tanta bandidagem. Temos que fazer algo para mostrar que não somos e não estamos incapazes" [sic] (BOECHAT, 2015, p. [S.I]); por fim, c) justificado por causa da corrupção do Governo Federal e do Congresso Nacional, como "O povo não linchou sozinho, com toda certeza, tinha mãos de políticos também, que só pensam em si mesmo e não fazem leis eficientes para acabar de vez com a impunidade desse pais. Acordem antes que seja tarde demais, o povo não aguenta mas" [sic] (BOECHAT, 2015, p. [S.I]).

Ainda sobre as justificações aparentes, foi possível detectar que a legitimação por racionalização (cadeia de raciocínios que busca justificar um conjunto de relações) (THOMPSON, 2002, p. 91) é o mais relevante modo de operador ideológico presente nos comentários. Na maioria das vezes, empreendida em forma de ressalvas (negação aparente)

\footnotetext{
${ }^{27}$ Para Theodor Adorno, o autoritário é "orgulhoso de ser um individualista e sempre temeroso de não ser igual aos outros, ciumento de sua independência e inclinado a se submeter cegamente ao poder e à autoridade" (ADORNO, 2016, p. [S.I]).
} 


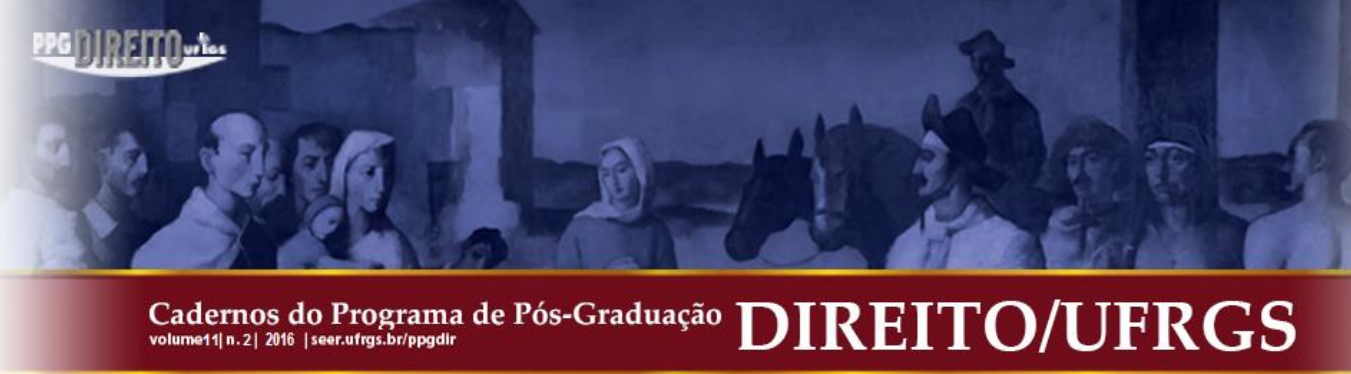

(van DIJK, 2010, p. 142), como "Não quero incentivar, mas infelizmente... (impunidade, delinquência, corrupção)"; "Até dá pena, mas... (impunidade, delinquência, corrupção)" etc. Os outros operadores ideológicos em destaque são a legitimação pela narrativização (histórias do passado, experiências, legitimam o presente) (THOMPSON, 2002, p. 91), como "Só quem foi assaltado sabe...", "Se você fosse assaltado..."; "Só quem não teve uma arma apontada sabe...” etc. e a legitimação pela universalização (interesses específicos são apresentados como gerais) (THOMPSON, apud COLARES, 2014, p. 130), como forma de corroborar a atuação dos justiceiros, incentivando a generalização de tal prática (geralmente sob forma de inversão - "não eles, nós é que somos as vítimas") (TOMAZI; ROCHA, 2013, p. 146-147).

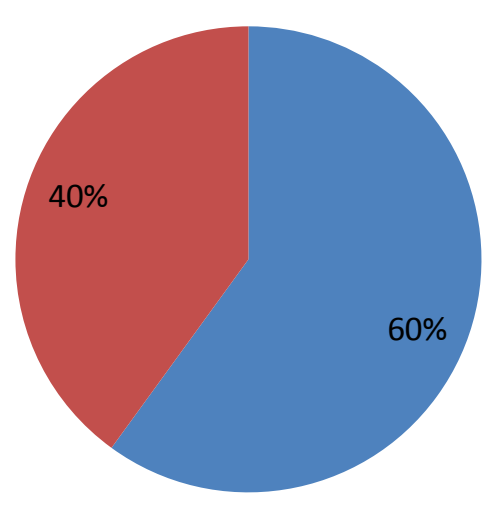

Figura 3 - Mapeamento geral dos comentários, em justificados aparentemente ou autoritários, a partir de internautas sobre o caso MA no Extra (Globo), em porcentagem.

Fonte: Elaborado pelo pesquisador.

\subsection{Relação entre Matérias e Comentários}

Já sob outra perspectiva, como demostrado, houve ainda uma grande disparidade entre o percentual de comentários que legitimavam e o dos que condenavam o linchamento, no decorrer das matérias. A diferença se mostrou tão visível a ponto de algumas possuírem $65 \%$ de comentários pró-linchamento e $35 \%$ contrários (como a $1^{\mathrm{a}}$, por exemplo), e outras (como a $14^{\mathrm{a}}$ e a $15^{\mathrm{a}}$, por exemplo) possuírem apenas comentários pró-linchamento (100\%). Esse fenômeno (efeito), a partir da análise discursiva crítica proposta, pode denotar diferentes modos de redação do material jornalístico (causa). 


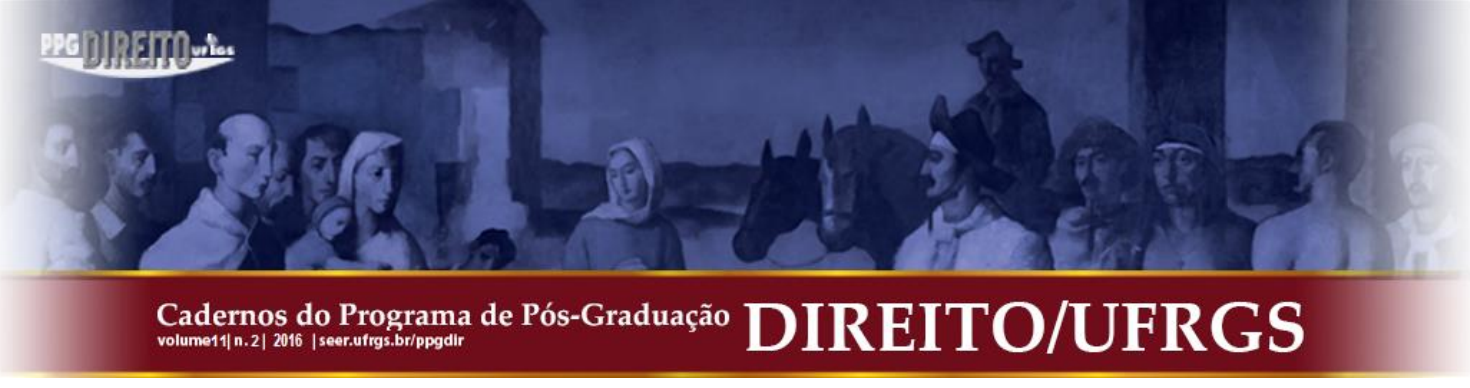

Nesse sentido, sobre a relação entre notícias veiculadas e comentários tecidos à matéria, algumas observações também são interessantes. Nota-se, por exemplo, que entre as matérias que incidiram menor quantidade de comentários punitivistas em sua plataforma $\left(1^{\mathrm{a}}, 4^{\mathrm{a}}, 5^{\mathrm{a}}, 7^{\mathrm{a}}\right.$, $9^{\text {a }}$ e $11^{\text {a }}$ ), predominava a escrita bastante sintética do jornalista (objetividade aparente), cujas matérias apresentavam prevalentemente cunho informativo. Por outro viés, entre as matérias que se mostravam com maior quantidade de comentários que exigiam o recrudescimento penal e legitimavam o linchamento $\left(12^{\mathrm{a}}, 13^{\mathrm{a}}, 14^{\mathrm{a}}, 15^{\mathrm{a}}, 16^{\mathrm{a}}, 17^{\mathrm{a}}, 18^{\mathrm{a}}, 20^{\mathrm{a}}\right)$, prevaleciam as de cunho opinativo, havendo a marcante presença de informações deveras acessórias e até mesmo extravagantes à matéria. ${ }^{28}$

Houve uma significante desconstrução da personalidade dos envolvidos (seja do menor ou de C.P.S.), paradoxalmente após serem vitimizados (matérias de número 12, 13, 16 e 17), no que Van Dijk (2010, p. 252-253) denominou de polarização discursiva (jogadas discursivas de inclusão e exclusão). A vitimização excessiva (matérias de número 14, 15, 18 e 20) da mesma maneira contribuiu para a legitimação "justiçamento" nos comentários da notícia. Nesse sentido, vejamos:

\begin{abstract}
A voz fina, o bigode ainda ralo e o corpo franzino, com cerca de $1,60 \mathrm{~m}$, aparentam menos do que os 17 anos. No lado esquerdo do rosto, no braço direito e nas costas, os vários hematomas e machucados, que persistem quatro dias após as agressões, contrastam com o ar infantil. Vítima da mesma sessão de espancamento que matou [C.P.S.], de 29 anos, o adolescente negou ontem, em novo depoimento prestado na Delegacia de Homicídios do Maranhão, que tenha saído de casa com a intenção de roubar (MARINATTO, 2015, p. [S.I]).

[...] A família do adolescente de 17 anos que sobreviveu a sessão de espancamento ocorrida na última segunda-feira, no bairro Jardim São Cristóvão, em São Luís, capital do Maranhão, afirmou, neste domingo, que vem recebendo ameaças. A mãe do menor, inclusive, pensa em tirá-lo de casa, contando, para isso, com a ajuda de amigos (MARINATTO, 2015, p. [S.I]).
\end{abstract}

Em vários tópicos há vitimização, a partir de expressões como voz fina, bigode ralo, corpo franzino, vítima de sessão de espancamento, ar infantil, vem sofrendo ameaças. Por outro lado, paradoxalmente, há a polarização forçada:

\footnotetext{
${ }^{28}$ Apesar de a objetividade plena ser impossível/indesejável (BARROS FILHO, 2003, p. 33-34), a divisão feita abaixo entre matéria informativa e opinativa se dá pelo fato de que algumas publicações são direcionadas ao fato (predominantemente informativas) - pretensiosamente despidas "de valorações, adjetivações ou da opinião pessoal do jornalista" (frisa-se, em aparente objetividade) (BARROS FILHO, 2003, p. 69), ao contrário das opinativas (que possuem latente exposição de opinião do redator/editor do jornal).
} 


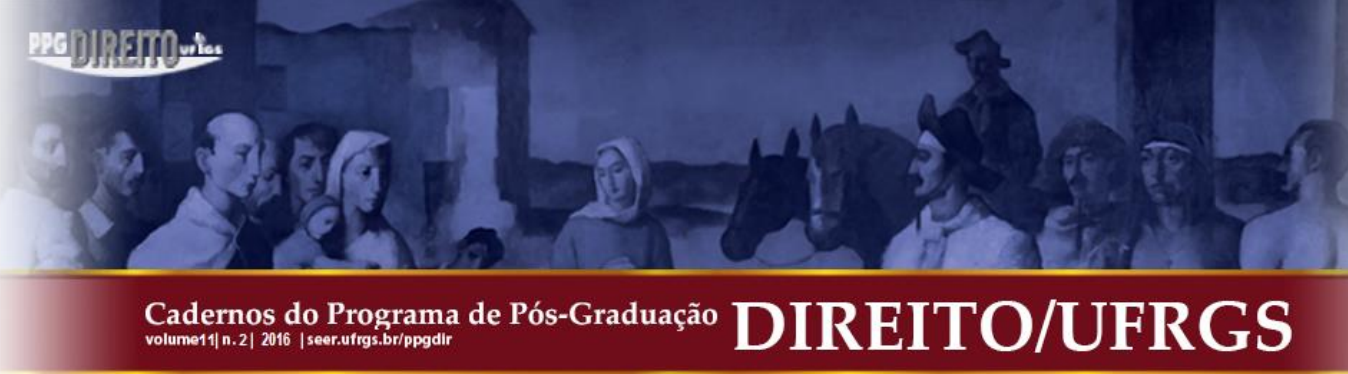

EXTRA: Seu filho já teve algum envolvimento com o crime?

$M \tilde{A E}$ : Soube que andou vendendo droga para um pessoal daqui, como "aviãozinho", e uma vez vieram dizer que tinha furtado um celular. Mas arma, por exemplo, eu tenho certeza de que ele nunca teve.

\section{EXTRA: Como foi a infância dele?}

$M \tilde{A E}$ : Jogava bola e brincava na rua como qualquer um. Ele parou de estudar no ano passado, na quinta série, mas sempre foi bom menino. Estava até trabalhando numa oficina, mas saiu há umas três semanas.

\section{EXTRA: E a relação com o pai, como é?}

$M \tilde{A E}$ : Meu marido bebe bastante, e às vezes fica violento. Já bateu nas crianças e em mim, o próprio (diz o nome do filho) já entrou no meio pra me defender. Na última quarta-feira, quando viu nosso menino em casa, ele quis expulsá-lo à força por causa dessa história toda, botar pra fora mesmo. Eu que não deixei (MARINATTO, 2015, p. [S.I]).

No coevo episódio, o adolescente é estigmatizado, ainda que resplandecido isso no discurso da própria mãe. Há uma narrativa da vida pregressa do menor, por meio de operadores argumentativos que evidenciam sua "má-personalidade" a partir de paradoxos: soube que era "aviãozinho" e que foi acusado de roubar um celular, mas arma nunca teve; parou de estudar na quinta série, mas sempre foi um bom menino; já foi expulso de casa, mas o próprio menor já defendeu a mãe contra o pai alcoólatra (MARINATTO, 2015, p. [S.I]).

Nesse sentido, seguem algumas transcrições retiradas da plataforma de comentários da mesma matéria Menor que sobreviveu a linchamento no Maranhão mostra ferimentos e diz que foi reconhecido por vizinho (MARINATTO, 2015, p. [S.I]): "É VERDADDE, O RAPAZINHO SAIU DE CASA PRA BRINCAR DE PIQUE MAS FOI DESVIRTUADO, NUNCA FEZ NADA ERRADO. P/O/R/R/R/R/A LEIA O QUE A PROPRIA MÃE FALA $\mathrm{DO} \mathrm{B} / \mathrm{O} / \mathrm{S} / \mathrm{S} / \mathrm{S} / \mathrm{T} / \mathrm{A}$ " [sic]; "E ficam jogando a responsabilidade toda para o Estado. Um professor não pode falar alto com um jovem hoje, que os pais ficam do lado dele, brigam com o professor e tiram sua autoridade. Depois choram pq os filhos se desviam" [sic]; "TÃO DE SACANAGEM, AGORA É UM SANTO. VAGABUNDO, 17 ANOS SEM QUERER ESTUDAR OU TRABALHAR. DA UMA BOLSA FAMILIA PRA ELE” [sic]. 


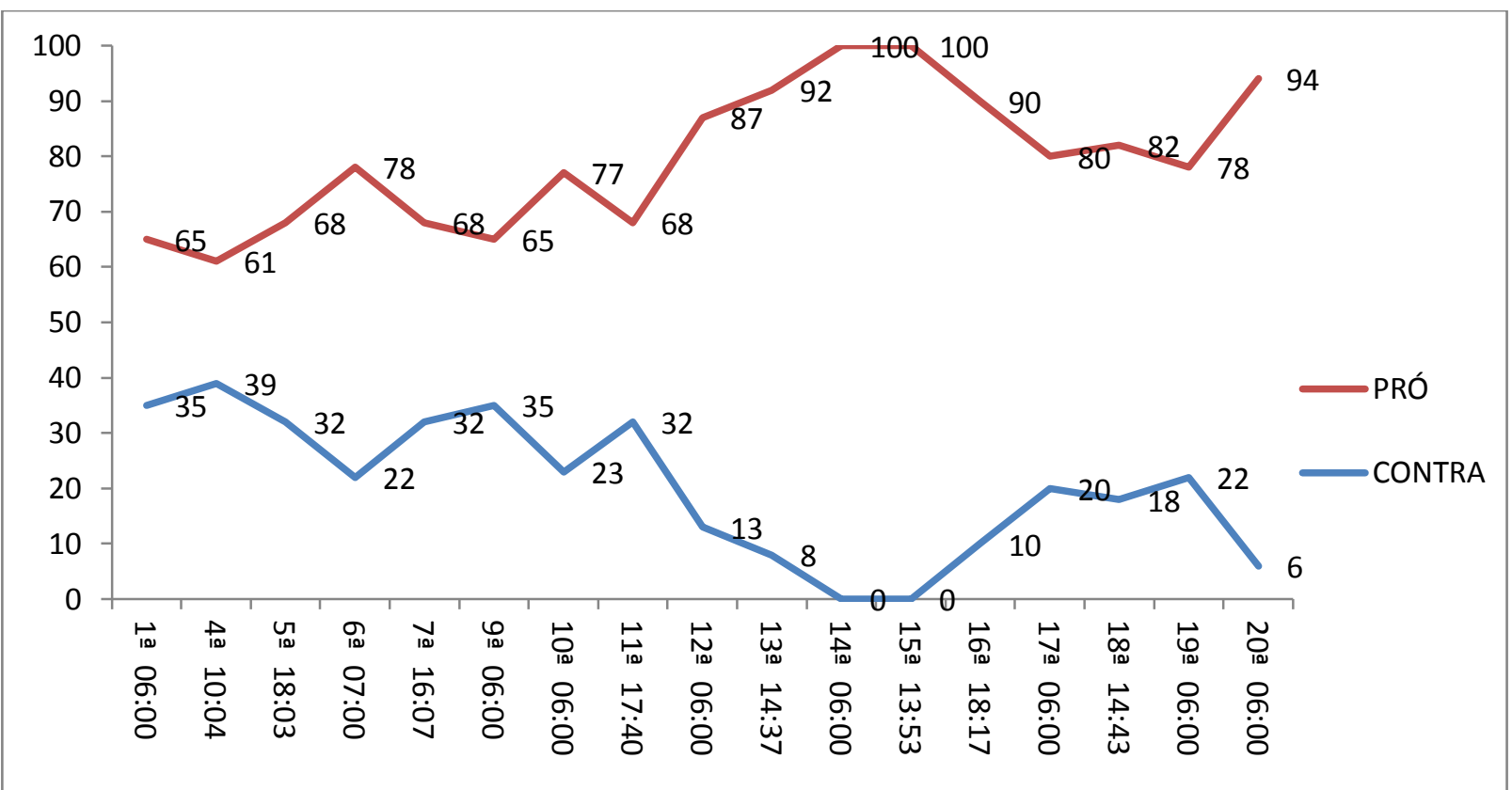

Gráfico 2 - Variação em percentual sobre comentários que legitimavam (pró) ou não legitimavam (contra) o linchamento no MA, a partir dos comentários analisados das matérias do Extra/Globo, ainda, desconsiderando os comentários neutros/dúbios.

Fonte: Elaborado pelo pesquisador.

A partir de tais dados, por amostragem, é possível asseverar que a mídia influencia a quantidade e o teor dos comentários tecidos à matéria quando o discurso extrapola a mera informação jornalística - como nos casos em que o suposto criminoso é apresentado reiteradamente em passivação, e principalmente, quando há, cumulativamente à vitimização, sua estigmatização, por meio da apresentação de seu histórico na criminalidade ou por outras condutas socialmente censuradas (evasão escolar, rebeldia etc.).

\section{CONSIDERAÇÕES FINAIS}

O presente estudo tratou de analisar qual é o "direito penal desejado" por internautas no Brasil, a partir de comentários gerados após a divulgação de matérias publicadas nos portais Extra (Globo) sobre um linchamento ocorrido em 6 de julho de 2015, em São Luís/MA. Ainda, o problema de pesquisa destacou a necessidade de investigar se esses comentários sofreram influência das matérias de jornal. Nestes termos, o estudo possibilitou algumas considerações.

Dessa feita, em resposta à primeira parte do problema de pesquisa, asseveramos que há um "direito penal desejado" expresso em comentários de mídias sociais, o qual se apresenta preponderantemente voltado ao por endurecimento das punições (mormente, de punições ao 


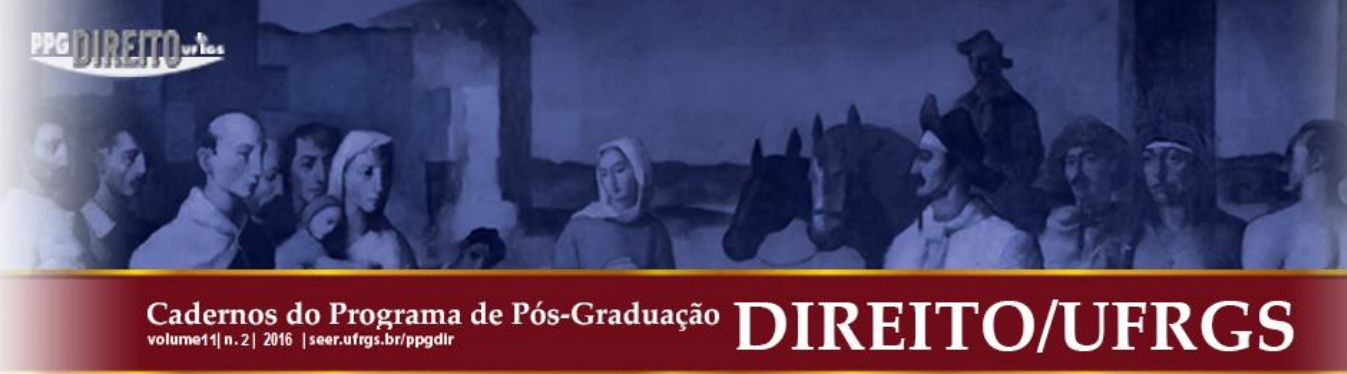

corpo) - no presente caso trazido à baila, a um posicionamento favorável ao "justiçamento" e execuções sumárias. Como pôde ser visto, uma suposta tentativa de assalto a um estabelecimento comercial foi suficiente para justificar e consolidar morte e agressões violentas às vítimas.

A segunda parte do problema de pesquisa, que trata da influência da mídia sobre a opinião pública, merece uma ponderação à parte. Notou-se que a forma pela qual o jornal apresentou o caso influenciou diretamente no conteúdo dos comentários, de modo que, quando a mídia social se apresentava em maior grau de objetividade aparente (matéria preponderantemente informativa), foram gerados comentários com maior grau de paridade entre os dissonantes (comentários pró-linchamento e contrários ao linchamento). Por outro lado, quando o jornal passou a inserir matérias de cunho opinativo, e indo em direção a questões aparentemente sem relação direta ao linchamento (perfil social e escolar das vítimas, por exemplo), tais matérias atraíram comentários explicitamente mais "punitivistas".

Assim, foi possível comprovar que, em muitas notícias, houve o direcionamento à estigmatização de C.P.S. e/ou do adolescente, ante a divulgação de fatos dispensáveis à conduta desses. Nesse sentido, torna-se inquestionável o papel do jornal Extra/Globo enquanto veículo formador da opinião pública, em relação ao "direito penal desejado" por internautas, nas mídias sociais.

Portanto, a mídia mostrou-se um campo importante e fecundo aos estudos direcionados ao direito penal no Brasil. Restou evidenciada a necessidade de se ponderar o discurso punitivo e sanguinário, que é cada vez mais crescente no Brasil, principalmente no que concerne aos ensejos parlamentares de dar voz à opinião pública em rede, no processo de tessitura da novel legislação penal.

A abertura à colaboração popular no processo de elaboração do Novo Código Penal, por meio de mídias sociais e demais plataformas similares que se regem pela fugacidade mediada (ao invés de convenções sociais onde se debata amplamente sobre o tema) - como vem sendo feito por legisladores —, a nosso ver, põe em xeque a apreciação dessa "opinião pública" como apanágio verdadeiramente democrático e de contribuição para a própria sociedade. 


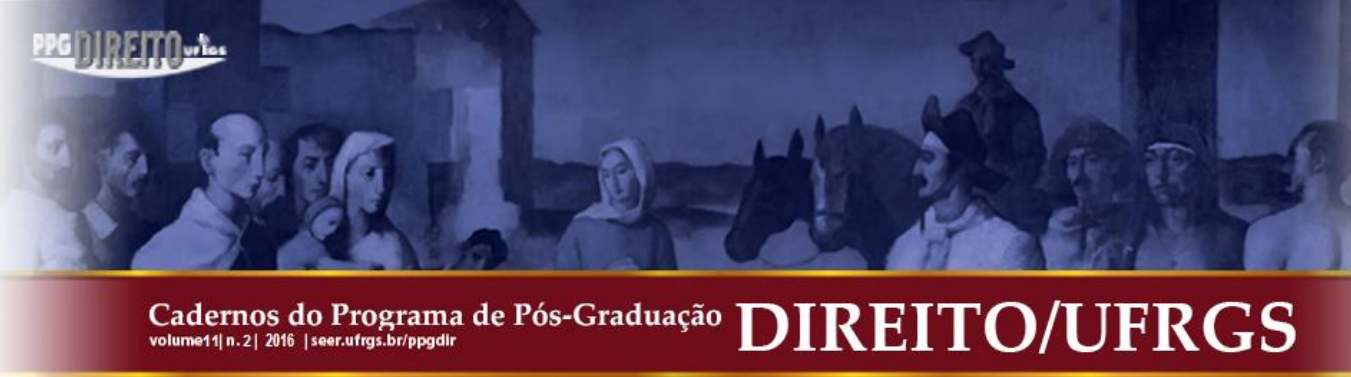

\section{REFERÊNCIAS}

ADORNO, T. W. Introdução à 'A personalidade autoritária'. Disponível em: $<$ http://adorno.planetaclix.pt/tadorno24.htm>. Acesso em: 30 mar. 2016.

ALCÂNTARA, D. CNI/Ibope: $46 \%$ da população é a favor da pena de morte. Noticias Terra, online. Disponível em: <http://noticias.terra.com.br/brasil/policia/cniibope-46-da-populacaoe-a-favor-da-pena-de-morte,0d88a6bfceflb310VgnCLD200000bbcceb0aRCRD.html $>$.

Acesso em: 26 fev. 2016.

AMPARO, V. Brasil é o país que mais faz linchamentos; Rio amarga vice-campeonato nacional. $O$ Dia, Rio de Janeiro, 26 jul. 2015. Disponível em: $<$ http://odia.ig.com.br/noticia/rio-de-janeiro/2015-07-26/brasil-e-pais-que-mais-fazlinchamentos-rio-amarga-vice-campeonato-nacional.html>. Acesso em: 28 jul. 2015.

ANÍBAL, F. 90\% apoiam redução da idade penal: Pesquisa nacional revela ainda que, para $64 \%$ dos brasileiros, punição mais rígida a adolescentes ajudaria a reduzir a violência. Gazeta do Povo, Curitiba, 14 jul. 2013. Disponível em: <http://www.gazetadopovo.com.br/vida-ecidadania/90-apoiam-reducao-da-idade-penal-c8e24o0vlosyiway5n00aryvi>. Acesso em: 25 fev. 2016.

ARAÚJO, T. Pressão nas redes que fez deputados mudarem opinião sobre idade penal constitui novo cenário político no País. Huffpost Brasil, São Paulo, 12 jul. 2015. Disponível em: $\quad<$ http://www.brasilpost.com.br/2015/07/12/redes-sociais-politicabrasil_n_7773618.html>. Acesso em: 21 abr. 2016.

BARROCAL, A. Se cadeia resolvesse, o Brasil seria exemplar. Carta Capital, São Paulo, 3 mar. 2015. Disponível em: http://www.cartacapital.com.br/revista/838/se-cadeia-resolvesse-4312.html. Acesso em: 18 ago. 2015.

BARROS FILHO, C. de. Ética na comunicação. 4. ed. São Paulo: Summus, 2003.

BATISTA, N. Mídia e sistema penal no capitalismo tardio. Discursos Sediciosos - crime, direito e sociedade, $\mathrm{n}^{\mathrm{o}}$ 12. Rio de Janeiro: Revan/ICC, $2^{\circ}$ semestre de 2002, p. 253-270.

BAUMAN, Z. Vida Líquida. Tradução de Carlos Alberto Medeiros. 2. ed. Rio de Janeiro: Zahar, 2009. 


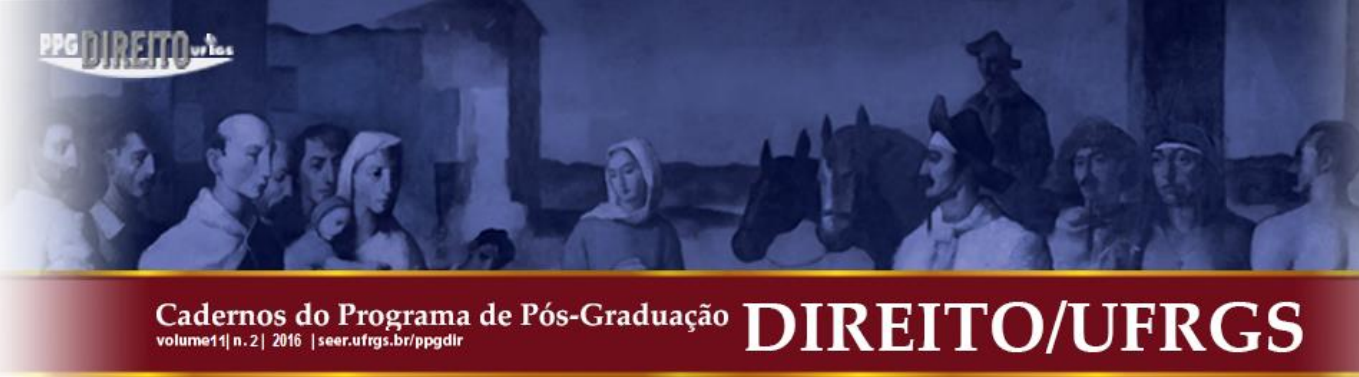

BAUMAN, Z. Modernidade Líquida. Tradução de Plínio Dentzien. Rio de Janeiro: Jorge Zahar, 2001.

BOECHAT, B. Assaltante é amarrado em poste e espancado até a morte por pedestres em São Luís. Extra, Rio de Janeiro, 7 jul. 2015. Disponível em: $<$ http://extra.globo.com/casos-depolicia/assaltante-amarrado-em-poste-espancado-ate-morte-por-pedestres-em-sao-luis16686215.html\#ixzz3jDJQw0ak>. Acesso em: 15 ago. 2015.

. Polícia identifica dois suspeitos de participação no linchamento em São Luís. Extra, Rio de Janeiro, 8 jul. 2015. Disponível em: <http://extra.globo.com/casos-de-policia/policiaidentifica-dois-suspeitos-de-participacao-no-linchamento-em-sao-luis16699223.html\#ixzz3jDKzAwFD>. Acesso em: 15 ago. 2015.

BRASIL. Senado Federal. Emenda ao Projeto de Lei do Senado n ${ }^{0}$ 236, de 2012 (NOVO CÓDIGO PENAL). Disponível em: $<$ http://www.senado.leg.br/atividade/materia/getPDF.asp?t=117224\&tp=1>. Acesso em: 21 abr. 2016.

BRASIL. Senado Federal. Projeto de Lei do Senado no 236, de 2012 (NOVO CÓDIGO PENAL). Disponível em: $\quad<$ http://www25.senado.leg.br/web/atividade/materias//materia/106404>. Acesso em: 25 fev. 2016.

BRASIL. Senado Federal. Violência no Brasil. Brasília, 2007. Disponível em: $<$ https://www.senado.gov.br/senado/datasenado/pdf/Pesquisa $\% 20$ Viol $\%$ C3\%AAncia $\% 20$ no\% 20Brasil\%20-\%20comunicado\%20\%C3\%A0\%20imprensa.pdf $>$. Acesso em: 22 abr. 2016.

BURKE, P. O que é História Cultural? Tradução de Sergio Goes de Paula. 2. ed. Rio de Janeiro: Jorge Zahar, 2008.

CARDOSO, G. Da Comunicação em Massa à Comunicação em Rede: Modelos Comunicacionais e a Sociedade de Informação. Disponível em: $<$ www.portalcomunicacao.com>. Acesso em: 22 jul. 2015.

CARVALHO, S. Antimanual de Criminologia. 6. ed. São Paulo: Saraiva, 2015.

CASTELLS, M. La Galaxia Internet. Barcelona: Areté, 2001. 


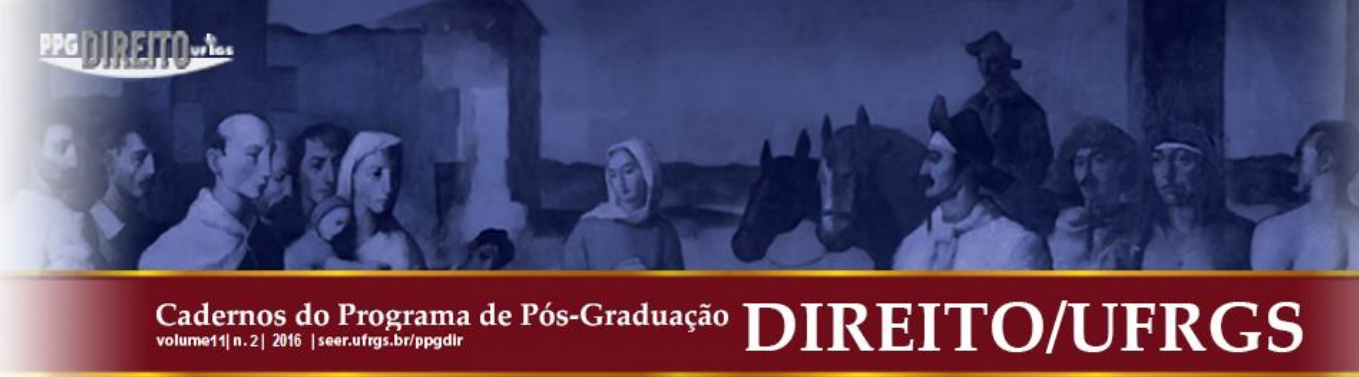

CERVI, E. U. A opinião pública e a publicada. O Globo, Rio de Janeiro, 11 ago. 2009. Disponível em: <http://observatoriodaimprensa.com.br/feitos-desfeitas/a-opiniao-publica-e-apublicada/> . Acesso em: 02 maio 2016.

CHAGAS, M. Novo Código Penal ganha destaque nas redes sociais. Exame, Brasília, 30 jun. 2012. Disponível em: <http://exame.abril.com.br/brasil/noticias/novo-codigo-penal-ganhadestaque-nas-redes-sociais>. Acesso em: 21 abr. 2016.

CHEVAlLIER, J. O Estado Pós-moderno. Belo Horizonte: Editora Fórum, 2009.

CHOMSKY, N. Mídia. Tradução de Fernando Santos. São Paulo: Martins Fontes, 2013.

COLARES, V. Análise Crítica do Discurso Jurídico (ACDJ): o caso Genelva e a (im)procedência da mudança de nome. ReVEL, v. 12, n.23, 2014. Disponível em: $<$ www.revel.inf.br >. Acesso em 09 jan. 2016.

CRESWELL, J. W. Investigação qualitativa e projeto de pesquisa. Tradução de Sandra Mallmann da Rosa. 3. ed. Porto Alegre: Penso, 2014.

CROCHIK, J. L. T.W. Adorno e a psicologia social. Psicologia e Sociedade, Porto Alegre, v. 20, n. 2, p. 297-305, 2008.

DIAS, W. Número de prisões indevidas no Rio passa de 50\%. Agência Brasil, Rio de Janeiro, 29 set. 2015. Disponível em: <http://agenciabrasil.ebc.com.br/direitos-humanos/noticia/201509/numero-prisoes-indevidas-rio-passa-50>. Acesso em: 22 abr. 2016.

DI REZENDE, M. Impunidade e corrupção. O Popular, Goiânia, 10 jul. 2015. Disponível em: $\quad<$ http://www.opopular.com.br/editorias/opiniao/da-reda\%C3\%A7\%C3\%A3o1.146393/impunidade-e-corrup\%C3\%A7\%C3\%A3o-1.895020>. Acesso em: 22 abr. 2016.

ENQUETE: $73 \%$ das pessoas são a favor de "fazer justiça" com as próprias mãos. O Estado, São Luís, 13 jul. 2015.2 Disponível $<$ http://imirante.com/oestadoma/noticias/2015/07/13/73-das-pessoas-sao-a-favor-de-fazerjustica-com-as-proprias-maos.shtml>. acesso em: 23 abr. 2016. 


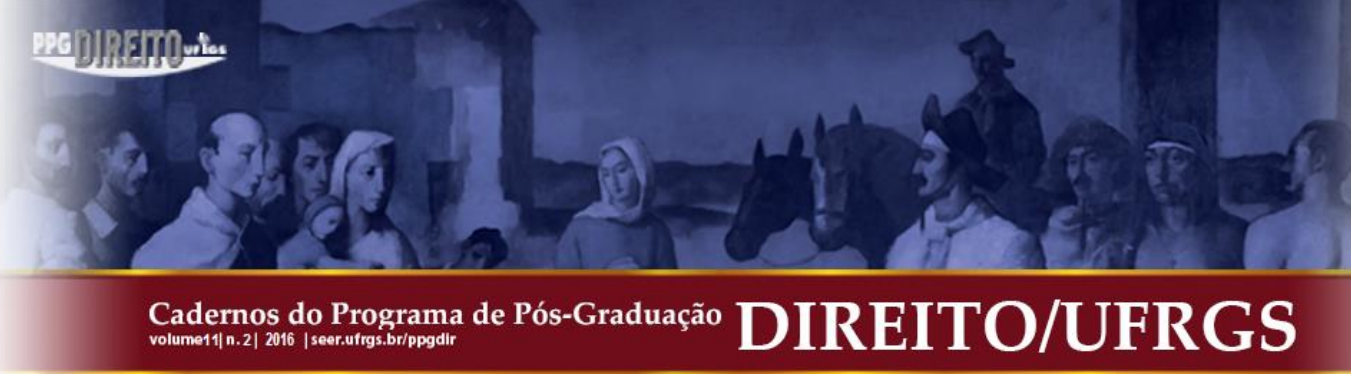

EXTRA. Internautas divergem sobre linchamento de assaltante no Maranhão. Extra, Rio de Janeiro, 8 jul. 2015. Disponível em: $<$ http://extra.globo.com/casos-de-policia/internautasdivergem-sobre-linchamento-de-assaltante-no-maranhao-16702348.html\#ixzz3jDKOznby>. Acesso em: 15 ago. 2015.

EXTRA. Caso de linchamento no Maranhão é o décimo noticiado no estado em 18 meses. Extra, Rio de Janeiro, 7 jul. 2015. Disponível em: <http:/extra.globo.com/casos-depolicia/caso-de-linchamento-no-maranhao-o-decimo-noticiado-no-estado-em-18-meses16691433.html\#ixzz3jDJw8EAB>. Acesso em: 15 ago. 2015.

EXTRA. Adolescente que estava com homem linchado no Maranhão se fingiu de morto para sobreviver. Extra, Rio de Janeiro, 08 jul. 2015. Disponível em: <http://extra.globo.com/casosde-policia/adolescente-que-estava-com-homem-linchado-no-maranhao-se-fingiu-de-mortopara-sobreviver-16705651.html\#ixzz3jDLUOaD4>. Acesso em: 15 jul. 2015.

FAIRCLOUGH, N. Discurso e Mudança Social. Tradução de Izabel Magalhães. Brasília: Editora Universidade de Brasília, 2001.

FARIAS, T. 43\% da população apoia PM que mata bandido. Blog do Tomi Farias, Rio de Janeiro, 25 nov. 2012. Disponível em: <http://tomifarias-politica.blogspot.com.br/2012/11/43da-populacao-apoia-pm-que-mata.html>. acesso em: 21 abr. 2016.

FREITAS, H.; OLIVEIRA, M.; SACCOL, A. Z., MOSCAROLA, J. O método de pesquisa survey. Revista de Administração, v. 35, n. 3, p. 105-112, jul./set., 2000. Disponível em: $<$ http://rausp.usp.br/wp-content/uploads/files/3503105.pdf $>$. Acesso em: 14 fev. 2016.

GARCIA, M. Das Redes para as Ruas. Disponível em: $<$ http://cienciahoje.uol.com.br/blogues/bussola/2013/06/das-redes-para-as-ruas $>$. Acesso em: 31 jul. 2015.

GENELHÚ, Ricardo. Do discurso da impunidade à impunização: o sistema penal do capitalismo brasileiro e a destruição da democracia. Rio de Janeiro: Revan, 2015.

GIDDENS, A. Modernidade e Identidade. Tradução de Plínio Dentzien. Rio de Janeiro: Jorge Zahar, 2002.

JAPIASSU, H. Interdisciplinaridade e Patologia do Saber. Rio de Janeiro: Imago, 1976. 


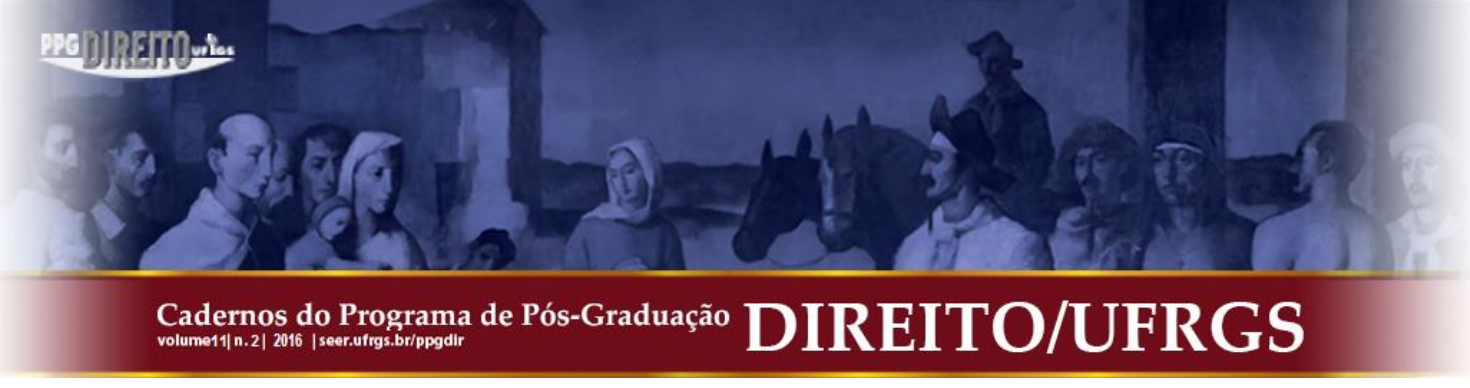

JINKINGS, D. Sociedade quer rigor no combate ao crime, aponta pesquisa da CNI. Agência Brasil, Brasília, 19 out. 2011. Disponível em: $<$ http://memoria.ebc.com.br/agenciabrasil/noticia/2011-10-19/sociedade-quer-rigor-nocombate-ao-crime-aponta-pesquisa-da-cni>. Acesso em: 22 abr. 2016.

KARAM, M. L. Recuperar o Desejo da Liberdade e Conter o Poder Punitivo. Escritos sobre a liberdade, v. 1. Rio de Janeiro: Lumen Juris, 2009.

LEITE, A. Ciência em tempos de reforma penal: a hora e a vez da ciência jurídico-penal brasileira. Empório do Direito, Florianópolis, 22 fev. 2015. Disponível em: $<$ http://emporiododireito.com.br/ciencia-em-tempos-de-reforma-penal-a-hora-e-a-vez-daciencia-juridico-penal-brasileira/>. Acesso em: 22 abr. 2016.

MADEIRO, C. População comemora e faz cortejo após PM matar dois suspeitos de assalto no MA. Uol Notícias, Maceió, 19 jan. 2016. Disponível em: $<$ http://noticias.bol.uol.com.br/ultimas-noticias/brasil/2016/01/19/populacao-comemora-e-fazcortejo-apos-pm-matar-suspeitos-de-assalto-no-ma.htm>. Acesso em: 21 abr. 2016.

MARINATTO, L. Após linchamento no Maranhão, dono de bar fechará as portas em definitivo. Extra, Rio de Janeiro, 14 jul. 2015. Disponível em: <http://extra.globo.com/casosde-policia/apos-linchamento-no-maranhao-dono-de-bar-fechara-as-portas-em-definitivo16754426.html\#ixzz3jDRVfCYd>. Acesso em: 15 ago. 2015.

. Após linchamento no Maranhão, filha de dono do bar assaltado diz: 'Desfecho foi bom para todos'. Extra, Rio de Janeiro, 9 jul. 2015. Disponível em: $<\mathrm{http}$ ://extra.globo.com/casos-de-policia/apos-linchamento-no-maranhao-filha-de-dono-dobar-assaltado-diz-desfecho-foi-bom-para-todos-16717285.html\#ixzz3jD MW7YfF>. Acesso em: 15 ago. 2015.

. 'Como estão colocando a cabeça no travesseiro?', pergunta família de linchado no Maranhão. Extra, Rio de Janeiro, 10 jul. 2015. Disponível em: <http://extra.globo.com/casosde-policia/como-estao-colocando-cabeca-no-travesseiro-pergunta-familia-de-linchado-nomaranhao-16721935.html\#ixzz3jDNgv8 3n>. Acesso em:15 ago. 2014.

. Homem morto após linchamento no Maranhão não tinha passagens pela polícia. Extra, Rio de Janeiro, 10 jul. 2015. Disponível em: <http://extra.globo.com/casos-depolicia/homem-morto-apos-linchamento-no-maranhao-nao-tinha-passagens-pela-policia16721967.html\#ixzz3jDNGS17F>. Acesso em: 15 ago. 2015. 


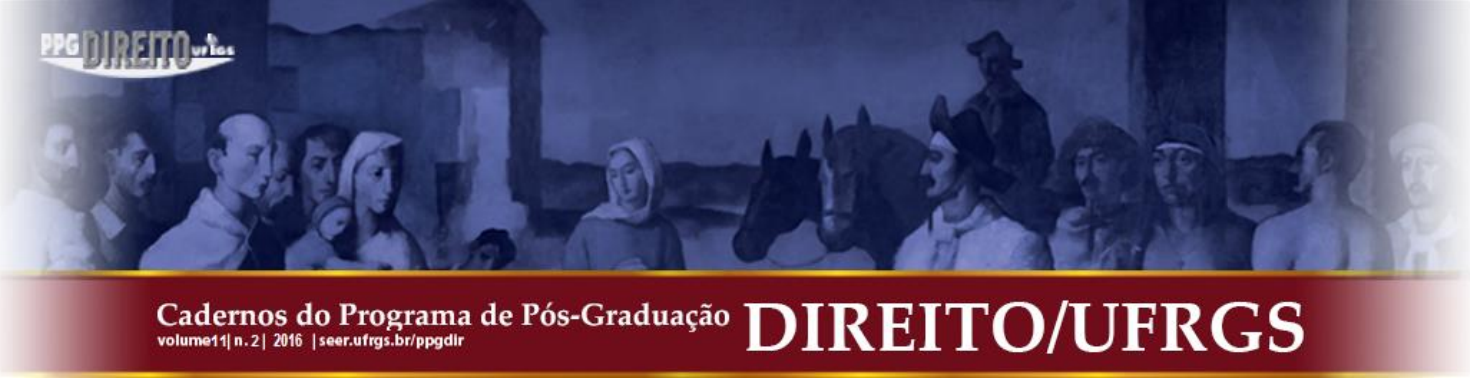

. Linchamento de jovem divide opinião de moradores do Maranhão. Extra, Rio de Janeiro, 12 jul. 2015. Disponível em: <http://extra.globo.com/casos-de-policia/linchamentode-jovem-divide-opiniao-de-moradores-do-maranhao-16739125. html\#ixzz3jDPnXpfl>. Acesso em: 15 ago. 2015.

Madrasta de linchado no Maranhão desmaia durante homenagem em cemitério. Extra, Rio de Janeiro, 12 jul. 2015. Disponível em: <http://extra.globo.com/casos-depolicia/madrasta-de-linchado-no-maranhao-desmaia-durante-homenagem-em-cemiteriosaber-que-se-foi-assim-o-pior-1674 1837.html\#ixzz3jDQXNvQi>. Acesso em: 15 ago. 2015.

. Madrasta de rapaz linchado no Maranhão teve filho assassinado há sete anos. Extra, Rio de Janeiro, 13 jul. 2015. Disponível em: <http://extra.globo.com/casos-depolicia/madrasta-de-rapaz-linchado-no-maranhao-teve-filho-assassinado-ha-sete-anos16743598.html\#ixzz3jDRCr6mP>. Acesso em: 15 ago. 2015.

. Menor que acompanhava homem linchado no Maranhão afirma que não saiu de casa

para assaltar. Extra, Rio de Janeiro, 11 jul. 2015. Disponível em: $<$ http://extra.globo.com/casos-de-policia/menor-que-acompanhava-homem-linchado-nomaranhao-afirma-que-nao-saiu-de-casa-para-assaltar-16733907. html\#ixzz3jDP6Y100>. Acesso em: 15 ago. 2015.

Menor que sobreviveu a linchamento fará reconhecimento de suspeitos na próxima sexta-feira. Extra, Rio de Janeiro, 15 jul. 2015. Disponível em: <http://extra.globo.com/casosde-policia/menor-que-sobreviveu-linchamento-fara-reconhecimento-de-suspeitos-na-proximasexta-feira-16766218.html\#ixzz3jDRsZLxr>. Acesso em: 15 ago. 2015.

Menor que sobreviveu a linchamento no Maranhão mostra ferimentos e diz que foi reconhecido por vizinho. Extra, Rio de Janeiro, 11 jul. 2015. Disponível em: $<\mathrm{http}$ ://extra.globo.com/casos-de-policia/menor-que-sobreviveu-linchamento-no-maranhaomostra-ferimentos-diz-que-foi-reconhecido-por-vizinho-16736632.html\#ixzz3jDPTg1 KB>. Acesso em: 15 ago. 2015.

Polícia deve fazer reprodução simulada de morte por linchamento no Maranhão.

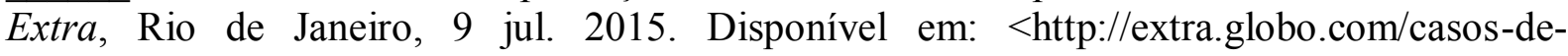
policia/policia-deve-fazer-reproducao-simulada-de-morte-por-linchamento-no-maranhao16719198.html\#ixzz3jDMupjhH>. Acesso em: 15 ago. 2015. 


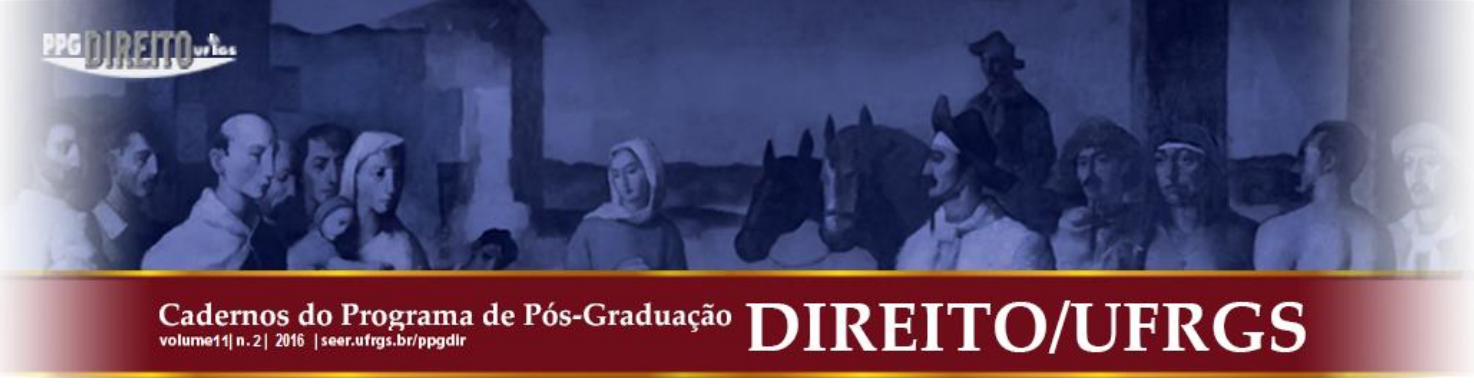

. Polícia do Maranhão vai apurar ameaças a menor que escapou de linchamento. Extra, Rio de Janeiro 12 jul. 2015. Disponível em: <http://extra.globo.com/casos-de-policia/policiado-maranhao-vai-apurar-ameacas-menor-que-escapou-de-linchamento16740678.html\#ixzz3jDQ74hY3>. Acesso em: 15 ago. 2015.

Rapaz linchado no Maranhão não seria pai. Extra, Rio de Janeiro, 13 jul. 2015. Disponível em: <http://extra.globo.com/casos-de-policia/rapaz-linchado-no-maranhao-naoseria-pai-foi-um-mal-entendido-diz-jovem-gravida-16747946.html\#ixzz3jDQsAa1 A>. Acesso em: 15 ago. 2015.

- Vídeo exclusivo mostra suspeitos de linchamento no Maranhão. Extra, Rio de Janeiro, 11 jul. 2015. Disponível em: <http://extra.globo.com/casos-de-policia/videoexclusivo-mostra-suspeitos-de-linchamento-no-maranhao-rv1-1-16729

443.html\#ixzz3jDOQnYjq>. Acesso em: 15 ago. 2015.

MELLO, B. População defende policial que matou dupla de assaltantes. A Gazeta, Rio Branco, 9 out. 2015. Disponível em: <http://agazetadoacre.com/noticias/populacao-defendepolicial-que-matou-dupla-de-assaltantes/>. Acesso em: 21 abr. 2016.

MENDES, I. S. M. Um caso de polícia: as reportagens policiais em dois jornais impressos brasileiros, abordadas à luz da Análise Crítica do Discurso. In: SILVA, D. E. G. (Org). Nas Instâncias do Discurso. Brasília: Editora Universidade de Brasília: Oficina Editorial do Instituto de Letras, 2005. p. 77-86.

MENEZES, N. Grupos anti-Dilma fazem maior protesto da história, de acordo com PM e Datafolha. $I G$, São Paulo, 13 de mar. 2016. Disponível em: $<$ http://ultimosegundo.ig.com.br/politica/2016-03-13/grupos-anti-dilma-fazem-maiorprotesto-da-historia-de-acordo-com-pm-e-datafolha.html>. Acesso em: 20 abr. 2016.

METADE dos brasileiros aceita tortura de acusados. Consultor Jurídico, São Paulo, 6 jul. 2012. Disponível em: <http://www.conjur.com.br/2012-jun-06/metade-brasileiros-concordatortura-criminosos-pesquisa>. Acesso em: 21 abr. 2016.

MONCLAIRE, S. A Constituição Desejada. Brasília: Senado Federal, Centro Gráfico, 1991. $1 \mathrm{v}$.

NASCIMENTO, M. Jornal mais lido do País, Extra comemora 15 anos de história. Segs, 27 maio 2013. Disponível em: <http://www.segs.com.br/segs/ arquivados/119101--jornal-maislido-do-pais-extra-comemora-15-anos-de-historia. html>. Acesso em: 18 de ago. 2015. 


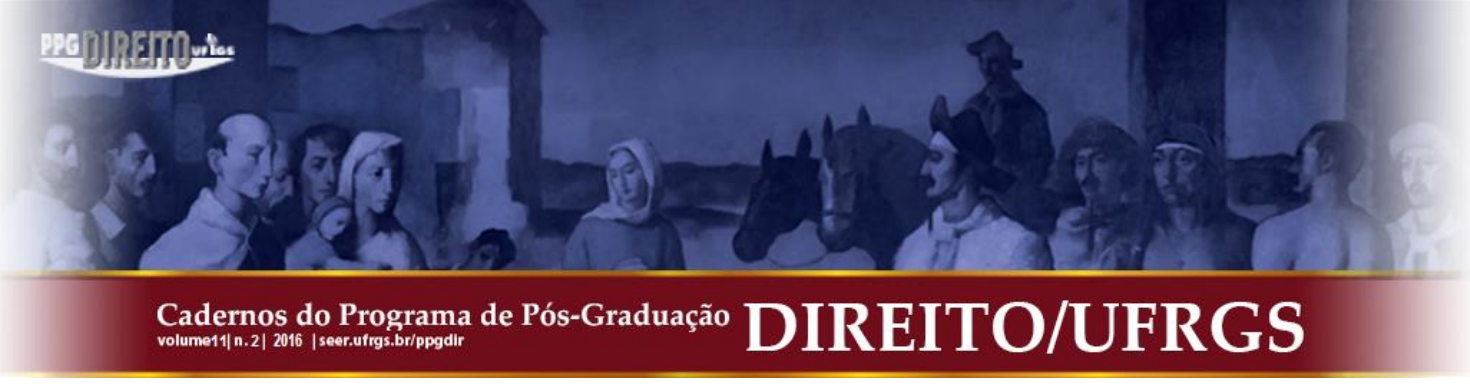

PAGNAN, R.; TUROLLO JR, R. Em 5 anos, polícia brasileira matou em média 6 pessoas por dia, diz estudo. Uol, São Paulo, 10 nov. 2014. Disponível em: $<$ http://www1.folha.uol.com.br/cotidiano/2014/11/1545847-em-5-anos-policia-brasileiramatou-em-media-6-pessoas-por-dia-diz-estudo.shtml>. Acesso em: 18 jul. 2015.

PARA 76\% da população, a lei penal não é severa no país. Consultor Jurídico, São Paulo, 10 nov. 2011. Disponível em: <http://www.conjur.com.br/2011-nov-10/76-populacao-lei-penalnao-severa-pesquisa-gv>. Acesso em: 22 abr. 2016.

PELUSO diz que Judiciário "não pode ouvir passivamente" as críticas da opinião pública. Gazeta do Povo, Brasília, 31 mar. 2011. Disponível em: $<$ http://www.gazetadopovo.com.br/vida-publica/peluso-diz-que-judiciario-nao-pode-ouvirpassivamente-as-criticas-da-opiniao-publica-ew4rylfz5mpltnqok6k9d7dxq $>$. Acesso em: 22 abr. 2016.

PEREIRA, H.; TELES, G. Condenado em segunda instância pode ir para a prisão, decide STF: Com a decisão do Supremo Tribunal Federal, acabou a farra de entrar com recurso na Justiça para não ir para a cadeia. Jornal da Globo, Brasília, 17 fev. 2016. Disponível em: <http://g1.globo.com/jornal-da-globo/noticia/2016/02/condenado-emsegunda-instancia-tem-que-ir-para-prisao-decide-stf.html>. Acesso em: 25 fev. 2016.

REDAÇÃO. Em capa histórica, jornal estampa atraso do Brasil. Carta Capital, São Paulo, 8 jul. 2015. Disponível em: <http://www.cartacapital.com.br/blogs/midiatico/em-capa-historicajornal-estampa-o-atraso-do-brasil-2887.html>. Acesso em: 15 jan. 2016.

RIBEIRO, M. Tortura é problema crônico em cadeias do Brasil, diz Human Rights Watch. $O$ Globo, Rio de Janeiro, 21 jan. 2014. Disponível em: <http://oglobo.globo.com/brasil/ torturaproblema-cronico-em-cadeias-do-brasil-diz-human-rights-watch-11355668>. Acesso em: 18 jul. 2015.

ROSA, E. Em média, há um linchamento ou tentativa de linchamento por dia no Brasil. Zero Hora, Porto Alegre, 27 jul. 2015. Disponível em: <http:// diariogaucho.clicrbs.com.br/rs/policia/noticia/2015/07/em-media-ha-um-linchamento-outentativa-de-linchamento-por-dia-no-brasil-4811304.html>. Acesso em: 28 jul. 2015.

SANTOS, J. C. dos. Os discursos sobre crime e criminalidade. Disponível em: $<$ http://icpc.org.br/wp- 


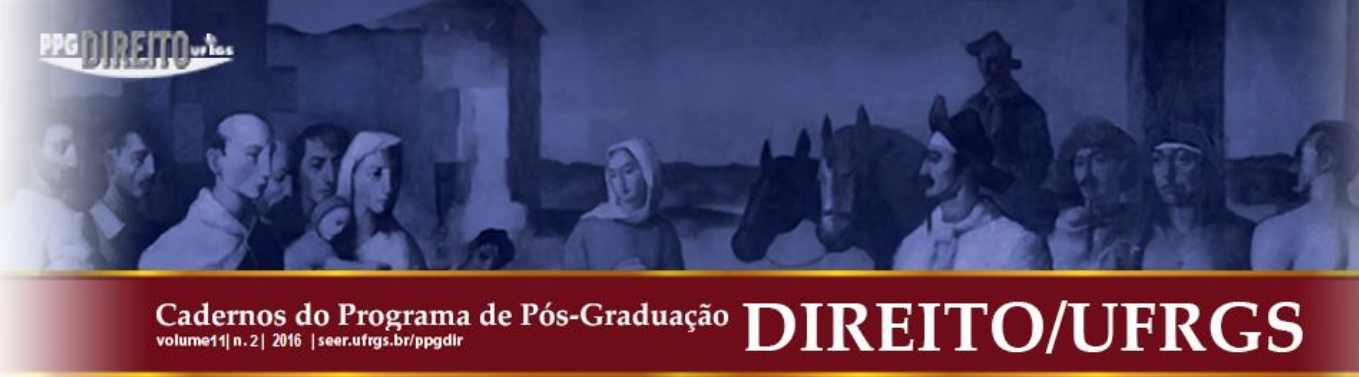

content/uploads/2012/05/os_discursos_sobre_crime_e_criminalidade.pdf $>$. Acesso em: 17 jun. 2016.

SCIREA, B. Para especialistas, apoio à morte de bandidos é reflexo de medo e intolerância. Zero Hora, Porto Alegre, 5 out. 2015. Disponível em: $<$ http://zh.clicrbs.com.br/rs/noticias/noticia/2015/10/para-especialistas-apoio-a-morte-debandidos-e-reflexo-de-medo-e-intolerancia-4863180.html>. Acesso em: 20 abr. 2016.

SILVA, R. B.; MENDES, J. P. S.; ALVES, R. S. L. O conceito de líquido em Zygmunt Bauman: contemporaneidade e produção de subjetividade. Athenea Digital, v. 15, n. 2, p. 249-264, 2015. Disponível em: <http://atheneadigital.net/article/view/v15-n2-silva>. Acesso em: 04 abril 2016.

SOHSTEN. N. F. V. Populismo penal no Brasil: o verdadeiro inimigo social que atua diretamente sobre o direito penal. Disponível em: $<\mathrm{http}: / / \mathrm{www}$.ambitojuridico.com.br/site/index.php/?n_link=revista_artigos_leitura\&artigo_id=13214\&revista_cad erno=3\#_ftn34>. Acesso em: 25 fev. 2016.

TAFFAREllo, R. F. Algo Podre no Guardião da Constituição. Disponível em: $<$ http://www1.folha.uol.com.br/poder/2016/02/1742882-algo-de-podre-no-guardiao-daconstituicao.shtml>. Acesso em: 25 fev. 2016.

TAVARES, A. Os 10 jornais mais lidos na Internet, segundo o IVC. GGN, São Paulo, 23 mar. 2014. Disponível em: <http://jornalggn.com.br/fora-pauta/os-10-jornais-mais-lidos-nainternet-segundo-o-ivc $>$. Acesso em: 18 ago. 2015.

TELlES, A. Definição de Rede Social e Mídia Social. Disponível em: $<$ http://www.midiatismo.com.br/definicao-de-rede-social-e-midia-social>. Acesso em: 20 fev. 2016.

- Ideología y cultura moderna: teoría crítica social en la era de la comunicación de masas. Trad. Gilda Fantinati Caviedes, 2. ed. Universidad Autónoma Metropolitana: Xochimilco-Mex: Casa Abierta al Tiempo, 2002.

TOMAZ JR, R. Para frear sanha punitiva, Wadih Damous apresenta projeto para Lei de Responsabilidade Politico-Criminal. Disponível em:

$<$ http://www.ptnacamara.org.br/index.php/component/k2/item/26103-para-frear-sanhapunitiva-wadih-damous-apresenta-projeto-para-lei-de-responsabilidade-politico-criminal $>$. Acesso em: 25 fev. 2016. 


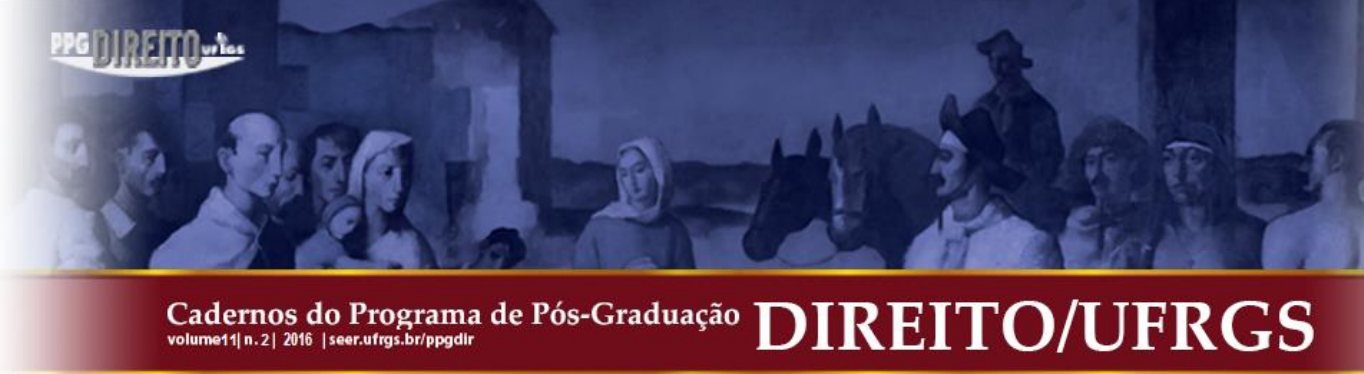

TOMAZI; M. M.; ROCHA, J. Análise crítica do discurso de pronunciamentos da polícia militar durante manifestações populares. In: SILVA, D. E. G. (org.) Cadernos de Linguagem e Sociedade, v. 14, n. 2, jul-set. 2013. Brasília: Thesaurus Editora, 2013. p. 137-159.

VAN DIJK, T. A. Discurso e Poder. 2. ed. São Paulo: Contexto, 2010.

VASCONCELlOS, M. País corre risco de aprovar pior Código Penal da história, criticam especialistas. Disponível em: <http://www.conjur.com.br/2015-mai-13/senado-analisa-piorcodigo-penal-historia-dizem-especialistas $>$. Acesso em: 25 fev. 2016.

VIEIRA, S. Pesquisa da USP mostra que cresce apoio da população à violência policial. Radio Senado, Brasília, 8 jun. 2012. Disponível em: $<$ http://www12.senado.gov.br/radio/1/noticia/pesquisa-da-usp-mostra-que-cresce-apoio-dapopulacao-a-violencia-policial>. Acesso em: 21 abr. 2016.

ZAFFARONI, R. E.; BATISTA, N.; SLOKAR, A.; ALAGIA, A. Direito Penal Brasileiro. Rio de Janeiro: Revan, 2003. v.1. p. 1-10.

ZAFFARONI, R. E.; PIERANGELI, J. H. Manual de Direito Penal Brasileiro. São Paulo: Revista dos Tribunais, 2008.

Submissão: $13 / 09 / 2015$

Aceito para Publicação: 20/07/2016 


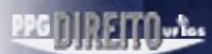

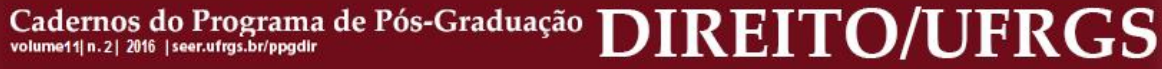

